\title{
WRF-Chem simulations in the Amazon region during wet and dry season transitions: evaluation of methane models and wetland inundation maps
}

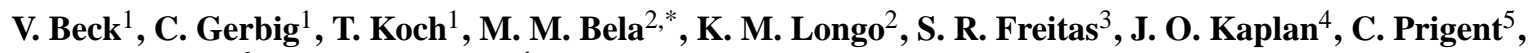 \\ P. Bergamaschi ${ }^{6}$, and M. Heimann ${ }^{1}$ \\ ${ }^{1}$ Max Planck Institute for Biogeochemistry, Hans-Knöll-Str.10, 07745 Jena, Germany \\ ${ }^{2}$ Center for Earth System Science (CCST), National Institute for Space Research (INPE), São José dos Campos, Brazil \\ ${ }^{3}$ Center for Weather Forecasting and Climate Studies, INPE, Cachoeira Paulista, Brazil \\ ${ }^{4}$ Ecole Polytechnique Fédérale de Lausanne, Switzerland \\ ${ }^{5}$ Laboratoire d'Etudes du Rayonnement et de la Matière en Astrophysique, Observatoire de Paris, Centre National de la \\ Recherche Scientifique, Paris, France \\ ${ }^{6}$ European Commission Joint Research Centre, Institute for Environment and Sustainability, Ispra Varese, Italy \\ *now at: Laboratory for Atmospheric and Space Physics and Department of Atmospheric and Oceanic Sciences, University of \\ Colorado, Boulder, CO, USA
}

Correspondence to: V. Beck (vbeck@bgc-jena.mpg.de)

Received: 29 June 2012 - Published in Atmos. Chem. Phys. Discuss.: 3 September 2012

Revised: 2 June 2013 - Accepted: 3 June 2013 - Published: 19 August 2013

\begin{abstract}
The Amazon region, being a large source of methane $\left(\mathrm{CH}_{4}\right)$, contributes significantly to the global annual $\mathrm{CH}_{4}$ budget. For the first time, a forward and inverse modelling framework on regional scale for the purpose of assessing the $\mathrm{CH}_{4}$ budget of the Amazon region is implemented. Here, we present forward simulations of $\mathrm{CH}_{4}$ as part of the forward and inverse modelling framework based on a modified version of the Weather Research and Forecasting model with chemistry that allows for passive tracer transport of $\mathrm{CH}_{4}$, carbon monoxide, and carbon dioxide (WRF-GHG), in combination with two different process-based bottom-up models of $\mathrm{CH}_{4}$ emissions from anaerobic microbial production in wetlands and additional datasets prescribing $\mathrm{CH}_{4}$ emissions from other sources such as biomass burning, termites, or other anthropogenic emissions. We compare WRFGHG simulations on $10 \mathrm{~km}$ horizontal resolution to flask and continuous $\mathrm{CH}_{4}$ observations obtained during two airborne measurement campaigns within the Balanço Atmosférico Regional de Carbono na Amazônia (BARCA) project in November 2008 and May 2009. In addition, three different wetland inundation maps, prescribing the fraction of inundated area per grid cell, are evaluated. Our results indicate
\end{abstract}

that the wetland inundation maps based on remote-sensing data represent the observations best except for the northern part of the Amazon basin and the Manaus area. WRF-GHG was able to represent the observed $\mathrm{CH}_{4}$ mixing ratios best at days with less convective activity. After adjusting wetland emissions to match the averaged observed mixing ratios of flights with little convective activity, the monthly $\mathrm{CH}_{4}$ budget for the Amazon basin obtained from four different simulations ranges from 1.5 to $4.8 \mathrm{Tg}$ for November 2008 and from 1.3 to $5.5 \mathrm{Tg}$ for May 2009. This corresponds to an average $\mathrm{CH}_{4}$ flux of $9-31 \mathrm{mg} \mathrm{m}^{-2} \mathrm{~d}^{-1}$ for November 2008 and $8-36 \mathrm{mg} \mathrm{m}^{-2} \mathrm{~d}^{-1}$ for May 2009.

\section{Introduction}

Atmospheric $\mathrm{CH}_{4}$ as the second most important greenhouse gas after carbon dioxide $\left(\mathrm{CO}_{2}\right)$ has recently received special attention in tropical regions (Frankenberg et al., 2008; Crevoisier et al., 2009; Petersen et al., 2010). In particular, the Amazon basin represents a strong natural source of $\mathrm{CH}_{4}$ through its emissions from anaerobic microbial production 
in wetlands (29.3 $\mathrm{Tg} \mathrm{a}^{-1}$ estimated by Melack et al., 2004) and contributes substantially to the global annual $\mathrm{CH}_{4}$ emissions of 500-600 Tg (IPCC, 2007). Beside natural sources of $\mathrm{CH}_{4}$ in the Amazon region, also anthropogenic sources such as $\mathrm{CH}_{4}$ emissions from biomass burning and other anthropogenic sources as ruminants or landfills and waste cannot be neglected (IPCC, 2007).

To quantify the $\mathrm{CH}_{4}$ source strength of the Amazon basin three different approaches have been used so far: (1) the calculation of the Amazon $\mathrm{CH}_{4}$ budget based on upscaling of observations from local flux measurements (Bartlett et al., 1988; Devol et al., 1990; Melack et al., 2004); (2) calculations of the source strength based on observed enhancements in atmospheric $\mathrm{CH}_{4}$ within the Amazon basin compared to $\mathrm{CH}_{4}$ mixing ratios observed at remote background surface station in Ascension Island and Ragged Point Barbados from the National Oceanic and Atmospheric Administration Earth System Research Laboratory (NOAA-ESRL) (Miller et al., 2007); and (3) estimations from global inversion systems (e.g. Bousquet et al., 2006; Chen and Prinn, 2006; or Bergamaschi et al., 2007, the latter using the zoom capability over South America). The latter two methods are also called "top-down" approach, as they use observations of atmospheric trace gases (e.g. $\mathrm{CO}_{2}, \mathrm{CH}_{4}$ ) within atmospheric transport models to retrieve surface-atmosphere fluxes as the atmosphere mixes and integrates surface fluxes that vary temporally and spatially (IPCC, 2007).

In contrast to northern mid-latitudes, where the top-down approach is widely used to estimate $\mathrm{CH}_{4}$ budgets utilising a forward and inverse modelling framework at regional scale and high horizontal resolution $(10-50 \mathrm{~km})$ (Vermeulen et al., 1999; Kort et al., 2008; Zhao et al., 2009; Pickett-Heaps et al., 2011), the tropical regions are still lacking those applications. Only Deutscher et al. (2010) estimated the tropical Australian wetland source using a regional modelling framework so far. To our knowledge such a forward and inverse modelling framework at regional scale for the estimation of the $\mathrm{CH}_{4}$ budget has not yet been implemented for the Amazon region. Of course, one requirement of applying such a modelling framework is sufficient availability and coverage of atmospheric observations within the region of interest. However, the only available atmospheric $\mathrm{CH}_{4}$ observations on regular time intervals in the Amazon basin are the stationary airborne profile measurements of Miller et al. (2007) since the year 2000. Also due to a lack of ground based atmospheric $\mathrm{CH}_{4}$ measurement stations, a regional scale modelling approach using atmospheric $\mathrm{CH}_{4}$ observations has not yet been conducted.

Now the availability of atmospheric observations in the Amazon region increases. Within the BARCA project two airborne measurement campaigns have been conducted in November 2008 (dry to wet season transition period, from here on referred to as "BARCA-A") and May 2009 (wet to dry season transition period, "BARCA-B"), covering almost the whole Amazon basin with vertical profiles in the

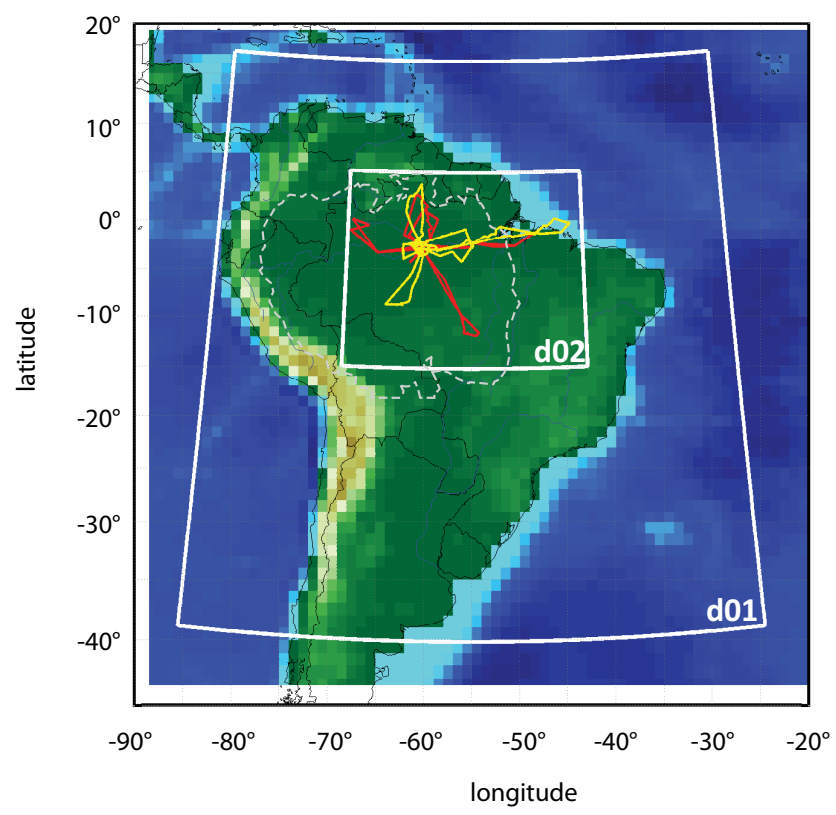

Fig. 1. Topographic map illustrating the position of the coarse domain $(\mathrm{d} 01-30 \mathrm{~km}$ horizontal resolution) and the nested domain (d02 - $10 \mathrm{~km}$ horizontal resolution). d02 covers the flight area of all flights conducted during BARCA-A and BARCA-B. The total flight track of BARCA-A is depicted in red and the total flight track of BARCA-B in yellow. The dashed line indicates the border of the Amazon lowland area as described in Melack et al. (2004).

lower troposphere up to $4000 \mathrm{~m}$ altitude. Continuous measurements of $\mathrm{CH}_{4}$ onboard an aircraft were performed for the first time in the Amazon (Chen et al., 2010; Beck et al., 2012). As in the next years the amount of atmospheric $\mathrm{CH}_{4}$ observations in the Amazon basin will grow substantially with the new built Amazonian Tall Tower Observatory (ATTO, http://www.mpic.de/ATTO.125.0.html) and the AMAZON Integrated Carbon Analysis project (AMAZONICA, http://www.geog.leeds.ac.uk/projects/amazonica/), the Amazon region will become a focus region for regional $\mathrm{CH}_{4}$ modelling studies to quantify the $\mathrm{CH}_{4}$ source strength of the Amazon basin using the top-down approach.

Emissions from wetlands are the dominant $\mathrm{CH}_{4}$ source in the Amazon region (Bustamante et al., 2010; Beck et al., 2012). Therefore, this study evaluates different processbased bottom-up models of $\mathrm{CH}_{4}$ emissions from anaerobic microbial production in wetlands in combination with different wetland inundation maps that indicate the area of inundation per grid cell against atmospheric observations obtained during BARCA. The purpose of the study is to serve as a benchmark study for future forward and inverse modelling applications (e.g. as described in Beck, 2012).

For our simulations we use the Weather Research and Forecasting model with chemistry (WRF-Chem) (http: //www.wrf-model.org/index.php) as atmospheric transport model. It was coupled to a biospheric $\mathrm{CO}_{2}$ flux model by 
Ahmadov et al. (2007), and augmented for online calculation of biospheric $\mathrm{CH}_{4}$ fluxes by Beck et al. (2011). It enables passive tracer transport simulations, i.e. without any chemical reactions, of $\mathrm{CO}_{2}, \mathrm{CH}_{4}$, and carbon monoxide (CO) (WRF Greenhouse Gas Model from hereon called "WRFGHG"). In our study we use the set-up of WRF-GHG to simulate $\mathrm{CH}_{4}$ mixing ratios over the Amazon basin during the two one-month time periods of the two BARCA campaigns (November 2008 and May 2009) to evaluate the performance of the model against the BARCA $\mathrm{CH}_{4}$ observations. For this purpose, we carry out simulations using combinations of two different wetland models (Kaplan, 2002; Walter et al., 2001a) and three wetland inundation maps of different horizontal resolution (Bergamaschi et al., 2007; Hess et al., 2009; Prigent et al., 2012). Furthermore, we evaluate the WRF-Chem meteorology on $10 \mathrm{~km}$ horizontal grid resolution to observations of meteorological variables during the airborne campaigns, precipitation observations, and radiosondes (November 2008 only).

The paper is structured as follows: Sect. 2 describes the modelling framework used for the simulations while Sect. 3 focuses on the two BARCA campaigns. In Sect. 4 the evaluation of the different simulations against the observations is presented. Section 5 concludes the paper.

\section{Modelling framework description}

To enable simulations of $\mathrm{CH}_{4}$ mixing ratios over the Amazon basin, the WRF-Chem model was modified to allow for tracer transport of $\mathrm{CH}_{4}$. The developments were accomplished within the WRF Greenhouse Gas Model (WRFGHG, Beck et al., 2011). Compared to simulations in Northern Hemispheric mid-latitudes (e.g. Ahmadov et al., 2007; Pillai et al., 2010, 2011), the WRF-Chem model had to be adapted to the tropics by using updated land-surface data for the Amazon region. Major sources of $\mathrm{CH}_{4}$ emissions in the Amazon region such as anaerobic microbial production in wetlands, biomass burning, or other anthropogenic sources that are represented in the model, are described in detail below with focus on the $\mathrm{CH}_{4}$ emissions from anaerobic microbial production in wetlands.

\subsection{WRF model set-up}

The principle component of our modelling system is the WRF-Chem model (for clarification: we use "WRF-Chem" to describe the WRF-Chem model without greenhouse gas contribution while "WRF-GHG" is used if greenhouse gas tracers are implemented), a non-hydrostatic, compressible model that allows for passive tracer transport (Grell et al., 2005). For our WRF-GHG simulations over the Amazon, we set up a coarse domain ("d01") covering most of South America with a horizontal grid distance of $30 \mathrm{~km}$ and a total area of $6600 \mathrm{~km} \times 6000 \mathrm{~km}$ with a two-way nested inner do- main ("d02"). It includes the BARCA flight area and most of the Amazon basin with a horizontal grid distance of $10 \mathrm{~km}$ and a total area of $2280 \mathrm{~km} \times 2760 \mathrm{~km}$. Figure 1 illustrates the location of the domains and the BARCA flight tracks for both airborne campaigns (BARCA-A red, BARCA-B yellow). The simulations use 41 vertical levels, of which 35 of them are identical to those used in the Brazilian developments on the Regional Atmospheric Modelling System (BRAMS) (Freitas et al., 2009). Additional six levels have been added in the planetary boundary layer for increased resolution. In order to account for the effects of recent changes in land use, e.g. through deforestation, more updated maps of land-surface data at higher resolution replace those of the standard WRF-Chem version. This concerns in particular albedo and greenness fraction. Therefore, observations from the Moderate Resolution Imaging Spectroradiometer (MODIS) with 30s resolution from the years 1992-1993 are used. The vegetation map now includes $1 \mathrm{~km}$ LANDSAT data from the years 1999-2000 (Belward, 1996; Sestini et al., 2003). As initial and lateral boundary conditions for all meteorological fields and sea surface temperature (SST), 6hourly analysis data from the European Centre for MediumRange Weather Forecast (ECMWF; http://www.ecmwf.int) with a horizontal resolution of about $35 \mathrm{~km}$ are utilised. The ECMWF soil moisture has been replaced by the GPNR soil moisture product (Gevaerd and Freitas, 2006), a hybrid product combining estimates from the Global Precipitation Climatology Project (GPCP) and the Tropical Rainfall Measuring Mission (TRMM). The runtime period ranges from 3-30 November 2008 (BARCA-A) and 3-30 May 2009 (BARCAB). Simulations are conducted for $30 \mathrm{~h}$ periods starting with a six hour meteorological spin-up at 18:00 UTC the previous day. An overview over the different configurations and physics options used for the WRF-Chem simulations is found in Table 1. Additionally, simulations with different planetary boundary layer schemes, microphysics schemes, and cumulus options have been carried out. These are evaluated against radiosondes and TRMM observations in Sect. 4.1.

\subsection{WRF-GHG development}

The online coupling of biospheric $\mathrm{CO}_{2}$ flux models to the WRF-Chem code was first described in Ahmadov et al. (2007, 2009), coupling the Vegetation Photosynthesis and Respiration Model (VPRM) (Mahadevan et al., 2008) to the WRF-Chem code (WRF-VPRM). WRF-GHG is the augmentation of WRF-VPRM to allow for tracer transport of $\mathrm{CH}_{4}, \mathrm{CO}_{2}$, and $\mathrm{CO}$ (described in detail in Beck et al., 2011). Online coupled $\mathrm{CH}_{4}$ flux models implemented within the WRF-GHG code are: (1) the wetland emission model of Kaplan (2002) calculating $\mathrm{CH}_{4}$ emissions of anaerobic microbial production in wetlands driven by soil moisture (SMOIS) and soil temperature (TSLB) from WRF-Chem; (2) the database of Sanderson (1996) for the calculation of $\mathrm{CH}_{4}$ termite emissions based on WRF-Chem vegetation 
types; and (3) the $\mathrm{CH}_{4}$ soil uptake model of Ridgwell et al. (1999) using several meteorological drivers including soil moisture (SMOIS), precipitation (RAINC and RAINNC), and potential evaporation (POTEVP) from WRF-Chem. For anthropogenic emissions of $\mathrm{CO}_{2}, \mathrm{CO}$, and $\mathrm{CH}_{4}$ including biomass burning emissions, external emission fields, e.g. as from the Emission Database of Global Atmospheric Research (EDGAR) are read into WRF-GHG.

All emissions are added at the first model level except for the biomass burning emissions. In case of biomass burning emissions the plumerise mechanism (Freitas et al., 2006; Grell et al., 2011) - already implemented in WRF-Chem was applied to determine the injection height of a biomass burning plume depending on heat fluxes, temperature, and wind speed. The contribution of different emission sources is separately determined using tagged tracers. A detailed description of all the flux models available with WRF-GHG, the code structure, new routines, as well as a user manual for WRF-GHG is found in Beck et al. (2011). Furthermore, a slightly modified version of the WRF-GHG is now part of the official WRF-Chem release version 3.4.

\subsection{Initial and lateral boundary conditions for $\mathrm{CH}_{4}$}

Eight so called "tagged tracers" are implemented in the WRF-GHG model for $\mathrm{CH}_{4}$ simulations. Each tracer, beside the total and the background atmospheric mixing ratio, is associated with a different source or sink process of $\mathrm{CH}_{4}$. Therefore, they allow a direct quantification of the contribution of the single processes. Methane contributions from wetlands, anthropogenic sources (except for biomass burning), biomass burning, termites, uptake of $\mathrm{CH}_{4}$ from the atmosphere by soil, are defined as separate tracers within WRFGHG for $\mathrm{CH}_{4}$ simulations over the Amazon. The set-up for the $\mathrm{CH}_{4}$ initial and lateral boundary conditions is similar to the set-up described by Ahmadov et al. (2007) for $\mathrm{CO}_{2}$. They used specific Lateral Boundary Conditions (LBCs) that are applied gradually over five grid cells within a relaxation zone for the coarse domain to adjust the values to those of the global fields. Global fields of $\mathrm{CH}_{4}$ mixing ratios that are used as initial and lateral boundary conditions are obtained from a TM5 transport model simulation (Bergamaschi et al., 2010). The TM5 simulation uses fluxes constrained by atmospheric observations from NOAA-ESRL surface stations and satellite observations from the Scanning Imaging Absorption spectrometer for Atmospheric CHartographY (SCIAMACHY) on $6^{\circ} \times 4^{\circ}$ horizontal resolution, 25 vertical levels, and daily time resolution. On the first day of the simulation period, all $\mathrm{CH}_{4}$ tracers are initialised with TM5 global fields. For the following simulation days, the tracer output at 00:00 UTC the previous day serves as initialisation of the tracer for the next day simulation period. The LBCs are taken from the TM5 global fields for all simulation days. To avoid negative values in the tracer variables that potentially occur with the advection scheme, all tracers are initialised with the
$\mathrm{CH}_{4}$ background mixing ratio (and also forced on the lateral boundaries). The $\mathrm{CH}_{4}$ background mixing ratio is transported as a separate tracer through the whole simulation and subtracted afterwards for the analysis of the single tracer components.

\subsection{Anthropogenic $\mathrm{CH}_{4}$ fluxes}

For anthropogenic $\mathrm{CH}_{4}$ emissions (not including biomass burning emissions), the Emission Database for Global Atmospheric Research (EDGAR, http://edgar.jrc.ec.europa.eu, Olivier et al., 1996, 1999) version 4.1 on $0.1^{\circ} \times 0.1^{\circ}$ horizontal resolution is utilised. EDGAR V4.1 provides annual emissions based on the year 2005. An updated version of EDGAR V4.1 for South American cities, with emissions adjusted based on the correlation between city vehicle density and mobile source emissions of $\mathrm{CO}$ and nitrous oxides $\left(\mathrm{NO}_{\mathrm{x}}\right)$ (Alonso et al., 2010), was used in this study. Additionally, a diurnal cycle peaking twice a day at 08:00 and 20:00 local time using a double Gaussian function as included in the standard WRF-Chem pre-processor PREP_CHEM_SRC1.0 (Freitas et al., 2011) is applied to the EDGAR V4.1 emissions. This pre-processor allows the processing of external emission inventories of different sources (anthropogenic, biogenic, biomass burning, volcanic emissions) as WRFChem input files. Additionally, a weekly cycle accounting for less industrial emissions on the weekends (multiplication factor of 0.83 for Saturdays, 0.67 for Sundays, and 1.1 for weekdays) has already been implemented into the WRFChem code. However, comparisons of WRF-GHG simulations with and without a weekly and diurnal cycle in the anthropogenic $\mathrm{CH}_{4}$ emissions indicate that the impact on the simulated $\mathrm{CH}_{4}$ mixing ratios in the Amazon basin is very small.

Biomass burning emissions are calculated using the Brazilian Biomass Burning Emission Model (3BEM; Longo et al., 2010) also included in PREP_CHEM_SRC-1.0 (Freitas et al. ,2011). Fire locations are derived from a combination of three different satellite products of the Geostationary Operational Environmental System - Wildfire Automated Biomass Burning Algorithm (GOES WF_ABBA), the Brazilian National Institute for Space Research (INPE) fire product based on the Advanced Very High Resolution Radiometer (AVHRR), and the Moderate Resolution Imaging Spectroradiometer (MODIS). GOES WF_ABBA additionally detects the burnt area of each detected fire pixel. A burnt area of $0.57 \mathrm{~km}^{2}$ for fire pixels detected by AVHRR and MODIS is used. For each detected fire pixel, the mass of emitted $\mathrm{CH}_{4}$ is calculated accordingly to the description in Longo et al. (2010) and Freitas et al. (2011). The diurnal cycle of the biomass burning emissions in South America included in the WRF-Chem model is described by a Gaussian function centred at 18:00 UTC following the typical diurnal cycle of fire occurrence in South America (Prins et al., 1998; Freitas et al., 2011). Additionally, PREP_CHEM_SRC- 
Table 1. Overview over WRF configurations, physics options, and updated surface maps used for the WRF-GHG simulations in the Amazon region.

\begin{tabular}{ll}
\hline Category & Configuration option \\
\hline Vertical coordinates & terrain-following hydrostatic pressure vertical coordinate \\
Basic equations & nonhydrostatic, compressible \\
Grid type & Arakawa C-grid \\
Time integration & 3rd order Rung-Kutta split-explicit \\
Spatial integration & 3rd and 5th order differencing for vertical and horizontal advection, respectively; both for momen- \\
& tum and scalars \\
Advection option & positive definite \\
2 Domain configuration & layers up to 20 km altitude (cors in mb) \\
& 180 s outer domain, 60 s inner domain \\
Time step & microphysics: WSM 5-class scheme; radiation: new version of the Rapid Radiative Transfer Model \\
Physic schemes & (RRTMG) for long- and shortwave radiation; cumulus: Grell-Dévényi and Grell 3 for outer and \\
& inner domain, respectively; surface layer: Monin-Obukhov; land-surface: NOAH-LSM; PBL: MYJ; \\
cumulus-radiation feedback turned on; shallow convection option turned off
\end{tabular}

1.0 provides the required input fields to use the plumerise model (Freitas et al., 2011) within WRF-GHG.

\subsection{Natural $\mathrm{CH}_{4}$ fluxes}

The dominant source of natural $\mathrm{CH}_{4}$ emissions is anaerobic microbial production of $\mathrm{CH}_{4}$ in wetlands, followed by $\mathrm{CH}_{4}$ emissions from termites (Wuebbles and Hayhoe, 2002). Uptake of atmospheric $\mathrm{CH}_{4}$ by soils is the only terrestrial sink of $\mathrm{CH}_{4}$ (IPCC, 2007). In this subsection, we briefly describe two models for the calculation of $\mathrm{CH}_{4}$ emissions from wetlands: the Kaplan wetland emission model (Kaplan, 2002, 2006; Drevet, 2008) - online integrated into the WRF-GHG code and the Walter wetland model (Walter et al., 1996, 2000, 2001a, b) in offline modus driven by WRF-Chem meteorology. Additional online-coupled models are a model for the simulations of $\mathrm{CH}_{4}$ uptake through soils (Ridgwell et al., 1999) and $\mathrm{CH}_{4}$ emissions from termites (Sanderson, 1996).

\subsubsection{Kaplan wetland emission model}

The Kaplan wetland emission model (Kaplan, 2002, 2006; Drevet, 2008) is based on a diagnostic approach to determine $\mathrm{CH}_{4}$ emissions from wetlands as fraction of the heterotrophic respiration (Christensen et al., 1996). The calculation of the heterotrophic respiration follows that of the LundPostdam-Jena (LPJ) model as described in Sitch et al. (2003), driven by a LPJ fast carbon pool and WRF-Chem soil moisture (mean of first and second layer) and soil temperature (first layer). At grid cells where the soil temperature is not defined, the skin temperature replaces the first layer soil temperature in the Kaplan wetland emission model. A "floodplain" factor of 0.19 introduced by Drevet (2008) determines the amount of $\mathrm{CH}_{4}$ emissions from the heterotrophic respiration. The model is online coupled within WRF-GHG and calculates $\mathrm{CH}_{4}$ fluxes for each model time step.

\subsubsection{Walter wetland model}

The Walter wetland model (Walter et al., 1996, 2001a, b; Walter and Heimann, 2000) is a process-based model for $\mathrm{CH}_{4}$ emissions from wetlands. The $\mathrm{CH}_{4}$ emissions depend on the position of the water table, the rate of methanogenesis, and the transport of $\mathrm{CH}_{4}$ to the atmosphere. A hydrological bucket model (Walter et al., 2001a) consisting of 170 layers with a thickness of $1 \mathrm{~cm}$ of each layer determines the position of the water table to separate between anaerobic layers of $\mathrm{CH}_{4}$ production and aerobic $\mathrm{CH}_{4}$ oxidation layers. The hydrological model is driven by the WRF-Chem meteorology using shortwave downward radiation (SWDOWN), ground heat flux (GLW), $2 \mathrm{~m}$ air temperature (T2), and precipitation (RAINC+RAINNC). Additional required variables such as net primary productivity (NPP) from the Biosphere Energy Transfer and Hydrology model (BETHY) (Knorr, 1997), terrain height (ETOPO5; Edwards, 1989), and the annual mean soil temperature of the upper soil layer taken from ECHAM simulations are provided by Walter et al. (2001a). Vegetation type dependent parameters required for the calculation of the transport of $\mathrm{CH}_{4}$ to the atmosphere (three different transport mechanisms: diffusion, ebullition, and plant-mediated transport) are derived from the WRF-Chem vegetation types as described in Beck et al. (2011). The WRF-Chem driven offline version of the Walter wetland model (driven offline due to a sequence of several small programmes) provides daily $\mathrm{CH}_{4}$ emissions. 


\subsubsection{Wetland inundation maps}

As $\mathrm{CH}_{4}$ emission from wetland are evolving under anaerobic conditions (Schlesinger, 1997), knowledge of the area, in which from a geographical point-of-view anaerobic conditions can occur, is required. The size of the area is dependent on water stage of the Amazon river and season (Hess et al., 2003). For the Kaplan wetland emission model, a location of the wetland area is required (Kaplan, 2002), while the Walter wetland model coupled to a hydrological model (Walter et al., 2001a) is also capable of identifying locations with anaerobic conditions. For comparison with equal conditions, a wetland inundation map indicating the fraction of inundation per grid cell (i.e. the percentage of the grid cell that is covered by wetland area) is utilised. It is multiplied by the $\mathrm{CH}_{4}$ wetland emissions from one of the two wetland flux models for each grid cell to derive the total amount of wetland $\mathrm{CH}_{4}$ emissions per grid cell. For this study, simulations of $\mathrm{CH}_{4}$ wetland emissions using the Walter wetland model with three different wetland maps have been carried out. The Kaplan wetland emission model is only used with the Kaplan wetland inundation map. The potential wetland map of Kaplan (Bergamaschi et al., 2007) has a horizontal resolution of $0.5^{\circ} \times 0.5^{\circ}$ and global coverage. The wetland map of Hess et al. (2009) (from hereon called "JERS-1SAR" wetland inundation map) giving the area of maximum inundation for the Amazon lowland region $(<500 \mathrm{~m})$ with a horizontal resolution of ca. $100 \mathrm{~m}$ is based on the Japanese Earth Resources Satellite 1 Synthetic Aperture Radar (JERS1SAR). Both are wetland inundation maps with wetland area constant in time. As the JERS-1SAR wetland inundation map does not cover the whole simulation domain, it is completed with the Kaplan wetland inundation map. As third wetland inundation map, the wetland inundation map of Prigent et al. $(2001,2007,2012)$ with $0.25^{\circ} \times 0.25^{\circ}$ horizontal resolution is a combined product of visible and near-infrared reflectance, the Normalised Difference Vegetation Index (NDVI) from AVHRR, passive microwave Special Sensor Microwave/Imager (SSM/I) measurements between 19 and $85 \mathrm{GHz}$, and active microwave backscattering coefficients at $5.25 \mathrm{GHz}$ from a scatterometer of the European Remote Sensing (ERS) satellite. The inundated area of the Prigent et al. (2007) wetland inundation map changes in time with monthly resolution, e.g. it accounts for less inundated areas during the dry season. For our study a monthly multiannual average of the years 1993-2003 is utilised (Prigent et al., 2012). Figure 2 illustrates the three above mentioned wetland inundation maps and the differences between those together with the BARCA flight tracks. It is also seen that the fraction of maximum inundation depends on the horizontal resolution of the wetland map is highest for the JERSISAR wetland inundation map with a horizontal resolution of $100 \mathrm{~m}$.

\subsubsection{Soil uptake model, termite and vegetation emissions}

The soil uptake model based on Ridgwell et al. (1999) is a process-based model calculating the consumption of atmospheric $\mathrm{CH}_{4}$ by soils. It is online coupled within WRF-GHG using WRF-Chem soil parameters and forcing meteorological fields such as precipitation, soil moisture, and soil temperature to calculate the oxidation rate of $\mathrm{CH}_{4}$ in soil. It utilises the total $\mathrm{CH}_{4}$ mixing ratio calculated by WRF-GHG to determine soil uptake. For grid cells that are dominated by wetlands (inundation fraction $>0.1$ ) the calculation of soil uptake is suppressed, as soil uptake does not take place in flooded areas.

The estimation of termite emissions uses the database established by Sanderson (1996), and is based on the product of biomass of termites (depending on the WRF vegetation type) and flux of trace gas emitted from those termites.

A detailed description of all flux models is found in Beck et al. (2011).

\section{BARCA campaigns}

Two airborne measurement campaigns have been conducted within the BARCA project, one at the end of the dry season in November 2008 (BARCA-A) and one at the end of the wet season in May 2009 (BARCA-B) in order to quantify the greenhouse gas budget of the Amazon basin. Beside measurements of greenhouse gases $\left(\mathrm{CO}_{2}, \mathrm{CH}_{4}\right)$, also other tracer such as CO (Andreae et al., 2012), ozone, and aerosols have been observed during a total of 27 flights. Figure 1 illustrates the flight track of both campaigns (BARCAA, red; BARCA-B, yellow) covering almost the whole Amazon basin. A number of 174 and 206 flasks were collected during BARCA-A and BARCA-B, respectively and analysed for $\mathrm{CH}_{4}$ (among other species) at the Jena Gaslab. Additionally, during BARCA-B an analyser based on cavityringdown spectroscopy was deployed on board the aircraft to obtain continuous measurements of $\mathrm{CO}_{2}, \mathrm{CH}_{4}$, and $\mathrm{H}_{2} \mathrm{O}$ (Chen et al., 2010). The analysis of the BARCA $\mathrm{CH}_{4}$ observations (see Beck et al., 2012 for details) indicates a strong source of $\mathrm{CH}_{4}$ in the Amazon with main contribution from $\mathrm{CH}_{4}$ emission of anaerobic microbial production in wetlands. For BARCA-A, a part of the variation in the $\mathrm{CH}_{4}$ mixing ratio could be explained by biomass burning. A comparison of the monthly budgets for different TM5-based inversions suggests values of $5.7 \pm 0.7 \mathrm{Tg}$ for November 2008 and $6.9 \pm 1.1 \mathrm{Tg}$ for May 2009 for the area of the Amazon lowland region (elevation < 500 m; cf. dashed line Fig. 1).

\section{Results and discussion}

First, the evaluation of three different meteorological setups of WRF-Chem against radiosondes and precipitation 


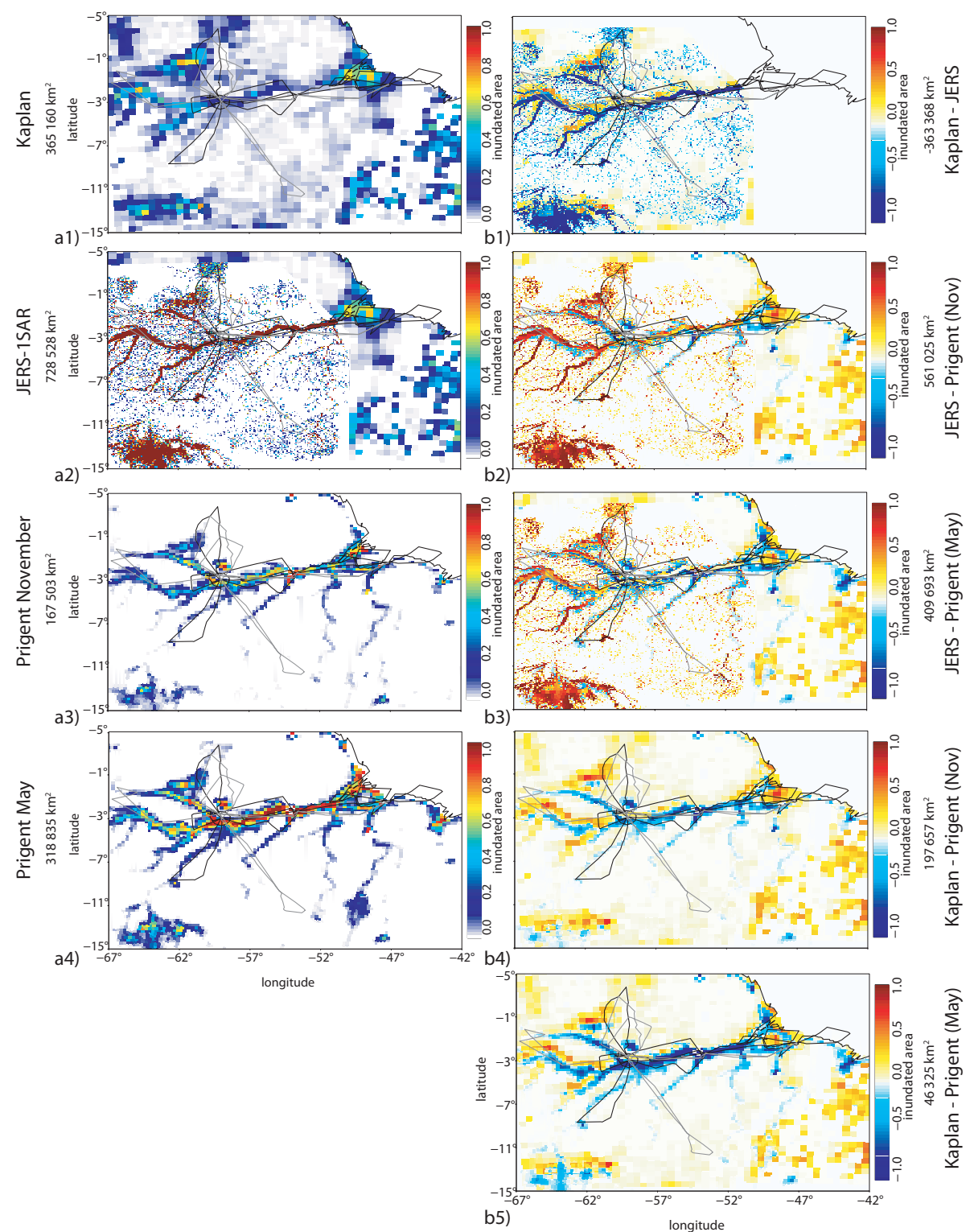

Fig. 2. Illustrated are three different wetland inundation maps (a) and the differences between these three wetland inundation maps (b). The wetland inundation maps indicate the fraction of inundated area per grid cell ranging from 0 to 1 and -1 to 1 for the differences between the wetland inundation maps. They are projected on the WRF nested grid (10 km horizontal grid distance). The BARCA flight tracks are overlaid (BARCA-A - black, BARCA-B - grey). (a1) denotes the Kaplan wetland map with a original horizontal resolution of $0.5^{\circ} \times 0.5^{\circ}$, (a2) the JERS-1SAR product with a original 3 arcsec horizontal resolution for the Amazon lowland area $(<500 \mathrm{~m})$ combined with the Kaplan potential wetland map, (a3) the Prigent wetland map for November (mean wetland inundation map for November of the years 1997-2003) on an original horizontal resolution of $0.25^{\circ} \times 0.25^{\circ}$, and (a4) the same map of the multi-annual average for May. In (b1)-(b5), the differences between the single wetland inundation maps are demonstrated. The numbers illustrates the total inundated wetland area or difference in the inundated wetland area for the $\mathrm{d} 02$ domain.

observations is described (Sect. 4.1). Then the simulated $\mathrm{CH}_{4}$ fluxes from the two wetland models (Kaplan wetland emission model and Walter wetland model) are compared against each other for the two simulation periods and against literature values in Sect. 4.2. In Sect. 4.3, the WRF-GHG $\mathrm{CH}_{4}$ simulations are compared to BARCA $\mathrm{CH}_{4}$ observations in different ways. First a comparison of two single flights in the eastern part of the Amazon region is accomplished (Sect. 4.3.1). Furthermore, we present an evaluation of the performance of WRF-GHG under "good" and "bad" weather conditions (i.e. days with little and much convective activity) in Sect. 4.3.2. In Sect. 4.3.3 the adjustment of the $\mathrm{CH}_{4}$ wetland emissions is described. It is followed by a comparison of the adjusted vertical profiles of the lower $4 \mathrm{~km}$ of 


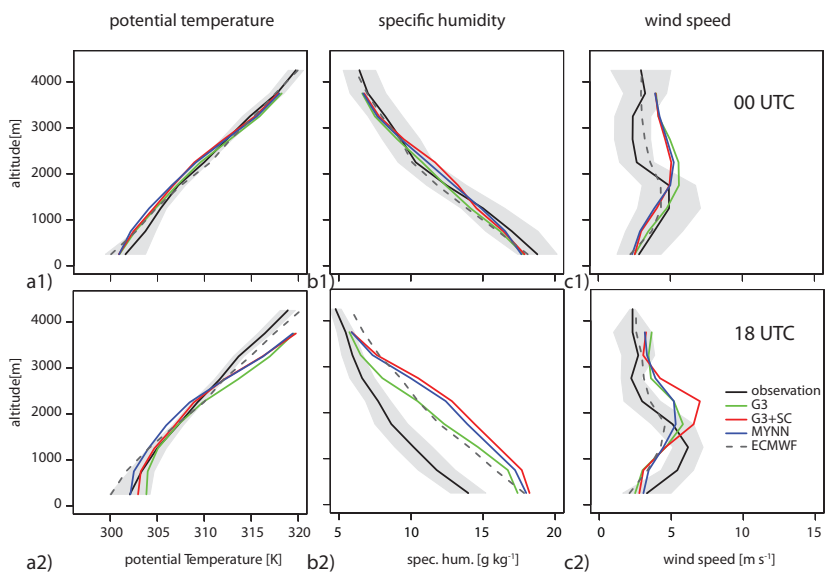

Fig. 3. Comparison of the meteorological variables potential temperature, specific humidity, and wind speed from different WRF meteorologies (green $-\mathrm{G} 3$, red $-\mathrm{G} 3+\mathrm{SC}$, blue $-\mathrm{MYNN}$ ) and from ECMWF (grey dashed) with radiosonde profiles for Manaus, averaged for the period of 18-29 November 2008 during BARCA$A$ at 00:00 UTC (upper panel) and 18:00 UTC (lower panel). The grey shaded area indicates the 1-sigma standard deviation of the radiosonde observations.

the atmosphere in five different regions in the Amazon basin (Sect. 4.3.4). Finally, a budget calculation of the Amazon region for the two one-month periods in Sect. 4.4 concludes the whole chapter.

\subsection{Meteorology}

Simulating atmospheric methane distributions requires an adequate representation of the main transport processes. To assess the impact of the choice of boundary layer and moist convection parameterizations, three different WRFChem meteorological set-ups are evaluated against independent observations from radiosondes in Manaus, Santarém, Belém, and Sao Gabriel de Cachoeira (during BARCA-A only). The set-up called "G3" using the Grell3 convective scheme, which allows spreading the convective cell over neighbouring grid cells, is described in Table 1. The set-up as described in Table 1 with additional shallow convection option is called "G3 + SC", while for the "MYNN" set-up the planetary boundary layer scheme changed from the MYJ (Mellor-Yamada-Janjic scheme) to MYNN (Mellor-YamadaNakanishi-Niino scheme - which is a further development of the MYJ scheme correcting for observed underestimations in the planetary boundary layer height), the shallow convection option was turned on and, the microphysics scheme changed from WSM-5 class to WSM-6 class scheme compared to G3. As an example, Fig. 3 demonstrates the comparison of the three different meteorological WRF set-ups as well as of the ECMWF data, used as meteorological initial and boundary conditions, to radiosondes for Manaus averaged over the time period of 18-29 November 2008. Here, we focus on the low- est $4 \mathrm{~km}$, the altitudes where also the BARCA airborne data were collected. At 00:00 UTC corresponding to 20:00 LT (Fig. 3, upper panel), the potential temperature and the specific humidity of all three set-ups are in good agreement with the observations (bias $=-0.17-0.51 \mathrm{~K}$ for the potential temperature, bias $=-0.04-0.46 \mathrm{~g} \mathrm{~kg}^{-1}$ for the specific humidity). Only the wind speed is overestimated by the WRFChem model (throughout all different meteorologies) in altitudes between $2000 \mathrm{~m}$ and $4000 \mathrm{~m}$ (bias $=1.8-2.1 \mathrm{~m} \mathrm{~s}^{-1}$ ), which is less notable in the ECMWF data (bias $=0.61 \mathrm{~m} \mathrm{~s}^{-1}$ ). In contrast, at 18:00 UTC (14:00 LT) all meteorologies show an overestimation of the potential temperature close to the ground and from altitudes of $2500 \mathrm{~m}$ on resulting in total biases of $0.30-1.42 \mathrm{~K}$. Even more crucial is the deviation of the specific humidity from the ground up to $4000 \mathrm{~m}$ altitude (bias $=2.68-4.12 \mathrm{~g} \mathrm{~kg}^{-1}$ ). Hereby, the simulations using the shallow convection scheme (G3+SC and MYNN) denote even higher deviations from the radiosondes observations ( 4.12 and $3.75 \mathrm{~g} \mathrm{~kg}^{-1}$ vs. $2.68 \mathrm{~g} \mathrm{~kg}^{-1}$ ). The positive deviations of the specific humidity at 18:00 UTC is already notable in the ECMWF fields (bias $=2.96 \mathrm{~g} \mathrm{~kg}^{-1}$ ) as forcing meteorology. This points to problems in the representation of the convective transport in both, the WRF-Chem and the ECMWF model. Comparisons at higher altitudes depict a problem with the implementation of the shallow convection scheme in WRF-Chem that leads to the unexpected low simulated specific humidity values (not shown). A test simulation with the G3 set-up using only the coarse d01 domain without nesting did not improve the results of the comparison.

Compared to northern mid-latitudes, where the WRFChem model is able to capture the well-mixed afternoon planetary boundary layer and shows more problems in capturing the stable nocturnal boundary layer (Ahmadov et al., 2007), the situation is different in the tropics. Here, the convective activity is not dominated by synoptic events, but rather by small scale and local effects such as convective cells, which are more difficult to represent by the model. As a measure for the performance of the convective transport in WRF-Chem, we compared WRF-Chem convective precipitation against TRMM precipitation observations with a horizontal resolution of $0.25^{\circ} \times 0.25^{\circ}$ and a temporal resolution of three hours. In general, the WRFChem simulations overestimate daily averaged mean precipitation (Fig. 4). During November 2008 WRF-Chem precipitation averages $0.50 \mathrm{~mm} \mathrm{~d}^{-1}$ compared to $0.24 \mathrm{~mm} \mathrm{~d}^{-1}$ as observed by TRMM. In May 2009, a similar overestimation $\left(0.47 \mathrm{~mm} \mathrm{~d}^{-1}\right.$ for WRF-Chem and $0.26 \mathrm{~mm} \mathrm{~d}^{-1}$ for TRMM) is seen. The amplitude of the diurnal cycle for precipitation for different regions of the nested domain is overestimated and the phasing is not always correct (not shown).

As the representation of the convective transport is crucial for an adequate representation of the atmospheric transport in the tropics, we selected the G3 meteorological setup to be used as "standard" meteorological set-up for our 


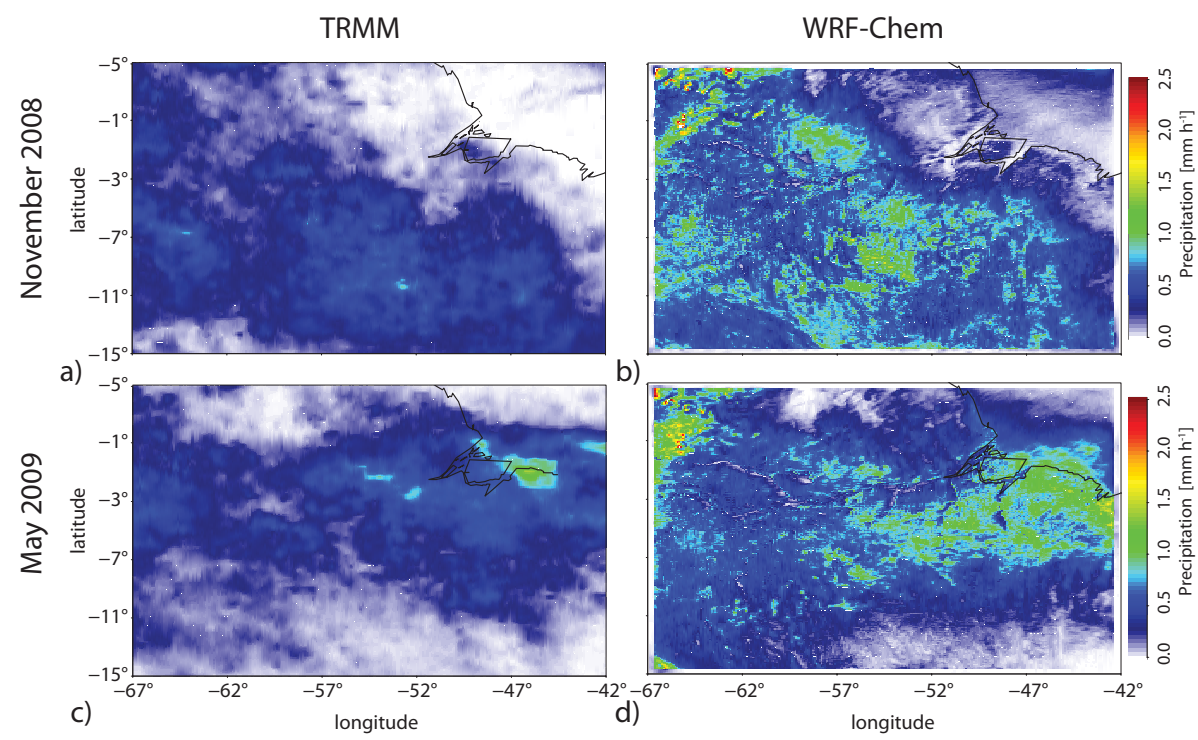

Fig. 4. Daily averaged precipitation $\left[\mathrm{mm} \mathrm{h}^{-1}\right.$ ] from the TRMM $3 B 42$ product (a, c) and the WRF simulations using the Grell 3 convection option without shallow convection (b, d). (a, b) illustrate the daily averaged precipitation for the period of 4-29 November 2008 (BARCA-A) and (c, d) for the period 4-29 May 2009 (BARCA-B).

WRF-GHG $\mathrm{CH}_{4}$ simulations. We based our selection on two criteria: (1) the comparison of the specific humidity against radiosondes, and (2) the mean average precipitation rate. The G3 set-up compares best to the radiosondes observations of the specific humidity and it has a similar mean daily average precipitation rate as the MYNN meteorological set-up (both $0.50 \mathrm{~mm} \mathrm{~d}^{-1}$ compared to $0.57 \mathrm{~mm} \mathrm{~d}^{-1}$ for $\mathrm{G} 3+\mathrm{SC}$ for November 2008 and $0.44 \mathrm{~mm} \mathrm{~d}^{-1}$ (G3) $0.44 \mathrm{~mm} \mathrm{~d}^{-1}$ (MYNN), and $0.51 \mathrm{~mm} \mathrm{~d}^{-1}(\mathrm{G} 3+\mathrm{SC})$ for May 2009).

A simulation without daily re-initialisation of the meteorological fields did not improve the results.

\subsection{Wetland fluxes}

The Kaplan wetland emission model and the Walter wetland model (in the following referred to "KWM" and "WWM", respectively) are both driven by the same WRF-Chem meteorological set-up (G3). KWM depends on the soil moisture and soil temperature obtained from WRF-Chem, while WWM uses soil temperature, ground heat fluxes, solar radiation, and precipitation from WRF-Chem. The offline simulations of WWM provide $\mathrm{CH}_{4}$ fluxes as daily mean values. The KWM methane fluxes are calculated online in WRF-GHG and written out on an hourly basis. The amplitude of the $\mathrm{CH}_{4}$ flux diurnal cycle can reach values up to $90 \mathrm{mg} \mathrm{m}^{-2} \mathrm{~d}^{-1}$ in extreme cases, but show an average value of $4 \mathrm{mg} \mathrm{m}^{-2} \mathrm{~d}^{-1}$ corresponding to $\sim 25 \%$ of the total daily flux on average for both months, November 2008 and May 2009. Therefore, we do not expect large impacts from neglecting the diurnal cycle of the $\mathrm{CH}_{4}$ wetland emissions calculated by WWM, especially for comparisons of WRF-GHG to airborne observations. Figure 5 illustrates the monthly mean
$\mathrm{CH}_{4}$ flux of KWM and WWM both using the Kaplan wetland inundation map for November 2008 (a) and May 2009 (b). The KWM emissions have been reduced by $76 \pm 4 \%$ for November 2008 and May 2009 compared to the original KWM. The adjustment of the wetland $\mathrm{CH}_{4}$ fluxes accounts for different meteorological drivers (especially differences in the soil temperature and soil moisture) and wetland inundation maps (different horizontal resolution) compared to the original models. For WWM the emissions are increased by $9 \pm 21 \%$ for both simulation periods. The adjustment of the wetland emissions from all models was chosen in a way that the mean observed $\mathrm{CH}_{4}$ mixing ratio of flights with a high percentage of wetland contribution and good representation of the atmospheric transport matches the mixing ratio of the corresponding WRF-GHG CH 4 simulation when extracted at the observation sampling location along the flight track during BARCA-B (see Sect. 4.3.3 for details).

The differences in the $\mathrm{CH}_{4}$ flux of both models are illustrated in Fig. 5a3-b3 for November 2008 and May 2009, respectively. For November 2008, $\mathrm{CH}_{4}$ emissions of WWM show higher values especially in the western part of the Amazon basin and the upper Rio Negro, while along the Amazon river between Manaus and Belém KWM shows similar $\mathrm{CH}_{4}$ emissions as WWM. In May 2009, KWM shows higher emissions compared to WWM along the Amazon river between Manaus and Belém and also along the Amazon delta, while WWM denotes higher emissions in the western part of the Amazon like in November 2008.

As WWM is sensitive to different wetland types through the plant-mediated transport mechanism that depends on the vegetation type (Walter et al., 2001a), locations with three 
Table 2. Comparison of the $\mathrm{CH}_{4}$ flux from the Kaplan wetland emission model (KWM) and the Walter wetland model (WWM) for grid cells specific for different wetland types (flooded forest, mixed flooded forest/open water, open water; cf. Hess et al. (2003) Fig. 8). The locations for the three different grid cells are illustrated as (A), (B), and (C) in Fig. 5a3-b3. In addition, literature values for the specific wetland types are denoted.

\begin{tabular}{|c|c|c|c|}
\hline & Kaplan (KWM) & Walter (WWM) & Literature references \\
\hline Flooded forest (A) & & & $150 \mathrm{mg} \mathrm{m}^{-2} \mathrm{~d}^{-1}$ \\
\hline Manirana (Tefe) $2.93^{\circ} \mathrm{S}, 64.93^{\circ} \mathrm{W}$ & & & Devol et al. (1990) \\
\hline November 2008 & $57 \mathrm{mg} \mathrm{m}^{-2} \mathrm{~d}^{-1}$ & $165 \mathrm{mg} \mathrm{m}^{-2} \mathrm{~d}^{-1}$ & $126 \mathrm{mg} \mathrm{m}^{-2} \mathrm{~d}^{-1}$ \\
\hline May 2009 & $96 \mathrm{mg} \mathrm{m}^{-2} \mathrm{~d}^{-1}$ & $161 \mathrm{mg} \mathrm{m}^{-2} \mathrm{~d}^{-1}$ & Bartlett et al. (1988) \\
\hline
\end{tabular}

Mixed flooded forest/open water (B)

Cabalina (Manacapuru) $3.43^{\circ} \mathrm{S}, 60.78^{\circ} \mathrm{W}$

November $2008 \quad 37 \mathrm{mg} \mathrm{m}^{-2} \mathrm{~d}^{-1} \quad 115 \mathrm{mg} \mathrm{m}^{-2} \mathrm{~d}^{-1}$

May $2009 \quad 58 \mathrm{mg} \mathrm{m}^{-2} \mathrm{~d}^{-1} \quad 146 \mathrm{mg} \mathrm{m}^{-2} \mathrm{~d}^{-1}$

\begin{tabular}{|c|c|c|c|}
\hline Open water $(\mathrm{C})$ & & & $74 \mathrm{mg} \mathrm{m}^{-2} \mathrm{~d}^{-1}$ \\
\hline Curuaí (Obidos) $1.95^{\circ} \mathrm{S}, 55.78^{\circ} \mathrm{W}$ & & & Bartlett et al. (1990) \\
\hline November 2008 & $43 \mathrm{mg} \mathrm{m}^{-2} \mathrm{~d}^{-1}$ & $37 \mathrm{mg} \mathrm{m}^{-2} \mathrm{~d}^{-1}$ & $44 \mathrm{mg} \mathrm{m}^{-2} \mathrm{~d}^{-1}$ \\
\hline May 2009 & $67 \mathrm{mg} \mathrm{m}^{-2} \mathrm{~d}^{-1}$ & $37 \mathrm{mg} \mathrm{m}^{-2} \mathrm{~d}^{-1}$ & Devol et al. (1990) \\
\hline
\end{tabular}

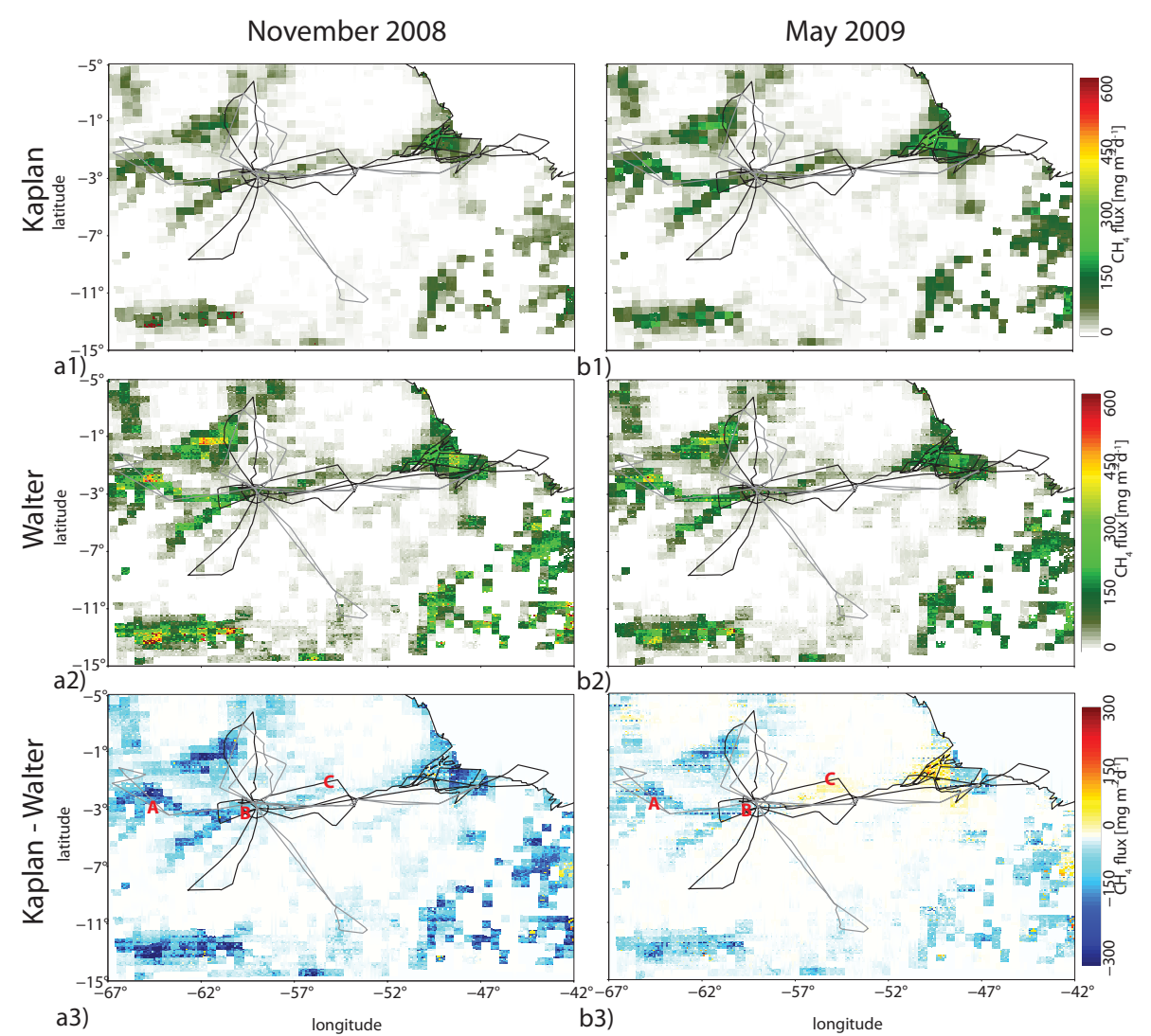

Fig. 5. Monthly mean $\mathrm{CH}_{4}$ fluxes of the Kaplan wetland emission model (KWM) and the Walter wetland model (WWM) for the "d02" domain, both using the Kaplan wetland inundation map for November 2008 (a1-a2) and May 2009 (b1-b2). The flux fields have already been adjusted according to the description in Sect. 4.3.3. The figures on the lower panel illustrate the difference in the $\mathrm{CH}_{4}$ flux between the KWM and WWM for November 2008 (a3) and May 2009 (b3). The locations of the grid cells with different wetlands types as further explained in Table 2 and Sect. 4.2 is illustrated in (a3) and (b3) with red letters (A - Manirana; B - Cabalina; C-Curuái). The flight track of the two BARCA campaigns is illustrated in black (BARCA-A) and grey (BARCA-B). 
different wetland types as described in Fig. 8 in Hess et al. (2003) were selected and the $\mathrm{CH}_{4}$ wetland flux from both models was compared. These are Manirana near Téfe flooded forest (A), Cabalina close to Manacapuru - mixture between flooded forest and open water (B), and Curuaí close to Obidos - mainly open water (C), indicated in Fig. 5a3-b3 with red letters. Table 2 illustrates the detailed comparison of both models at the prescribed location and a comparison to literature values for different wetland types. The general agreement with the available observations of $\mathrm{CH}_{4}$ fluxes suggests that both models are able to simulate the $\mathrm{CH}_{4}$ wetland flux magnitude for the Amazon basin in the right order of magnitude.

The nested domain averaged $\mathrm{CH}_{4}$ flux for all wetland grid points is somewhat lower for KWM compared to WWM $\left(22 \mathrm{mg} \mathrm{m}^{-2} \mathrm{~d}^{-1}\right.$ for May 2009 and $13 \mathrm{mg} \mathrm{m}^{-2} \mathrm{~d}^{-1}$ for November 2008 vs. $30 \mathrm{mg} \mathrm{m}^{-2} \mathrm{~d}^{-1}$ and $37 \mathrm{mg} \mathrm{m}^{-2} \mathrm{~d}^{-1}$, respectively). Both models simulate the $\mathrm{CH}_{4}$ emissions in a similar order of magnitude. In addition, WWM allows for a separation of the contributions of the different pathways of $\mathrm{CH}_{4}$ to the atmosphere, such as diffusion, ebullition (formation of gas bubbles containing $\mathrm{CH}_{4}$ that are released to the atmosphere), and plant-mediated transport. The mean contribution of the three different pathways for the whole $\mathrm{d} 02$ domain for WWM in November 2008 results in $30 \%$ plantmediated transport, $47 \%$ ebullition, and $23 \%$ diffusion. For May 2009, the ratio is slightly different (34\% plant-mediated transport, $44 \%$ ebullition, and $22 \%$ diffusion). Compared to Bartlett et al. (1988) who estimated the ebullitive flux to account for $48 \%$ in open water and $54 \%$ in flooded forest areas, the ebullitive contribution of WWM to the $\mathrm{CH}_{4}$ transport to the atmosphere is in the same order of magnitude. However, Crill et al. (1988) estimated $70 \%$ contribution of ebullition. Up to this study WWM has only been validated against observations from a swamp region in Panama in the tropics (Walter and Heimann, 2000). Due to the agreement with the observations as indicated above, we consider the WWM as suitable for the Amazon basin.

\subsection{Comparison to BARCA observations}

In total four WRF-GHG simulations using the G3 meteorological set-up (Table 1, also Sect. 4.1) with different combinations of wetland models and wetland inundation maps (named WKK, WWK, WWJ, and WWP in the following the second letters indicate the wetland model "K" for KWM and "W" for "WWM", while the third letter stands for the choice of wetland inundation map "K" for Kaplan, "J" for JERS-1SAR, and "P" for Prigent) have been carried out (see Table 3). In this section, a comparison of two selected flights under different weather conditions is presented first. It illustrates the impact of the quality of the representation of the atmospheric transport on the simulated tracer distribution. Second, an evaluation of the simulations of the $\mathrm{CH}_{4}$ mixing ratio distribution is presented for weather conditions that are better represented in WRF vs. those that are not well represented. The $\mathrm{CH}_{4}$ wetland contribution is adjusted taking only flights with a good representation of the atmospheric transport in the model. Finally, the comparison of the adjusted WRF-GHG simulations to vertical profiles of the BARCA $\mathrm{CH}_{4}$ observations in five different regions of the Amazon is shown.

To compare the WRF-GHG simulations to the BARCA airborne observations, the WRF-GHG simulations have been extracted at the grid cell closest to the location of each observation point. For BARCA-A, the location of the flask observations is used as extracting point while for BARCA-B the locations of the $3 \mathrm{~s}$ continuous observations are utilised except for the flights $8-10$ where no continuous observations are available due to instrument failure. For these flights, the locations of the flask observations are taken to extract the model values. Bias is calculated as the mean of the residuals originating from the model - observation difference of each observation point.

\subsubsection{Comparison for two selected flights during BARCA-B}

To illustrate the importance of the representation of the atmospheric transport in the model, we selected two flights in the eastern part of the Amazon basin during BARCA-B with different quality of representation in the model as examples for a case study: one flight where WRF-GHG shows problems in the representation of the atmospheric transport (FLT 721 May 2009 18:00-21:00 UTC, left panel Fig. 6a-c) and one flight where the atmospheric transport is better reproduced by WRF-Chem (FLT 1126 May 2009 13:00-16:00 UTC, right panel Fig. 6d-f) during the $3 \mathrm{~h}$ time period of the flight. For both flights, WRF-GHG simulations of WWP are utilised and the wetland emissions have not been adjusted.

For FLT 7, the TRMM observations indicate convective events (precipitation is used as a proxy for convective events during the 3-h flight period here) along the flight path (a) while WRF-Chem produces in general more convective events (or precipitation) compared to the TRMM observations for this period, but almost no convective event along the flight track. This is also illustrated in the comparison of the specific humidity (b), where WRF-Chem simulations show a much more stratified distribution of the specific humidity than what was observed $\left(r^{2}=0.895\right.$, bias $\left.=0.632 \mathrm{~K}\right)$. It is clear at first sight that the modelled $\mathrm{CH}_{4}$ mixing ratio of WRF-GHG does not represent well the observed $\mathrm{CH}_{4}$ mixing ratio for this flight $\left(r^{2}=0.30\right.$, bias $\left.=-22 \mathrm{ppb}\right)$. WRF-GHG simulations with in total four different convective schemes have been carried out for the time period of 19-21 May 2009. None of the simulations was able to capture the convective transport properly as comparisons against TRMM precipitation patterns demonstrate (not shown).

The situation is different for FLT 11 (right panel, Fig. 6df). Here again the WRF-Chem model simulates more convective events compared to the TRMM observations. However, 
Table 3. Overview of the different WRF-GHG CH 4 simulations using different configurations for wetland models (Kaplan, 2002 or Walter et al., 2001a) and wetland inundation maps (Kaplan (Bergamaschi et al., 2007); JERS-1SAR (Hess et al., 2009); Prigent (Prigent et al., 2012)). The wetland inundation maps indicate the fraction of inundation per grid cell. All simulations use the Grell 3 convective scheme without the shallow convection options, the plumerise mechanism for biomass burning emissions, and initial and lateral boundary conditions for $\mathrm{CH}_{4}$ from TM5. The number of wetland grid points shows the values for November and May for the Prigent wetland inundation map. Adjustment factors are chosen to match the mean atmospheric $\mathrm{CH}_{4}$ observations for selected flights with a good representation of the atmospheric transport in the model in May 2009 (BARCA-B).

\begin{tabular}{|c|c|c|c|c|c|}
\hline $\begin{array}{l}\text { WRF } \\
\text { simulation }\end{array}$ & $\begin{array}{l}\text { Wetland } \\
\text { model }\end{array}$ & $\begin{array}{l}\text { Wetland } \\
\text { inundation map }\end{array}$ & $\begin{array}{l}\text { Horizontal resolution } \\
\text { wetland map }\end{array}$ & $\begin{array}{l}\text { Wetland grid points } \\
\text { in } \mathrm{d} 02 \text { domain }\end{array}$ & $\begin{array}{l}\text { Wetland adjustment } \\
\text { factor }\end{array}$ \\
\hline WKK & Kaplan (KWM) & Kaplan & $0.5^{\circ} \times 0.5^{\circ}$ & 30670 & $-76 \pm 4 \%$ \\
\hline WWK & Walter (WWM) & Kaplan & $0.5^{\circ} \times 0.5^{\circ}$ & 30670 & $+9 \pm 21 \%$ \\
\hline WWJ & Walter (WWM) & JERS-1SAR & ca. $100 \mathrm{~m}$ & 28081 & $-27 \pm 16 \%$ \\
\hline WWP & Walter (WWM) & Prigent & $0.25^{\circ} \times 0.25^{\circ}$ & $15006 / 15826$ & $-55 \pm 12 \%$ \\
\hline
\end{tabular}

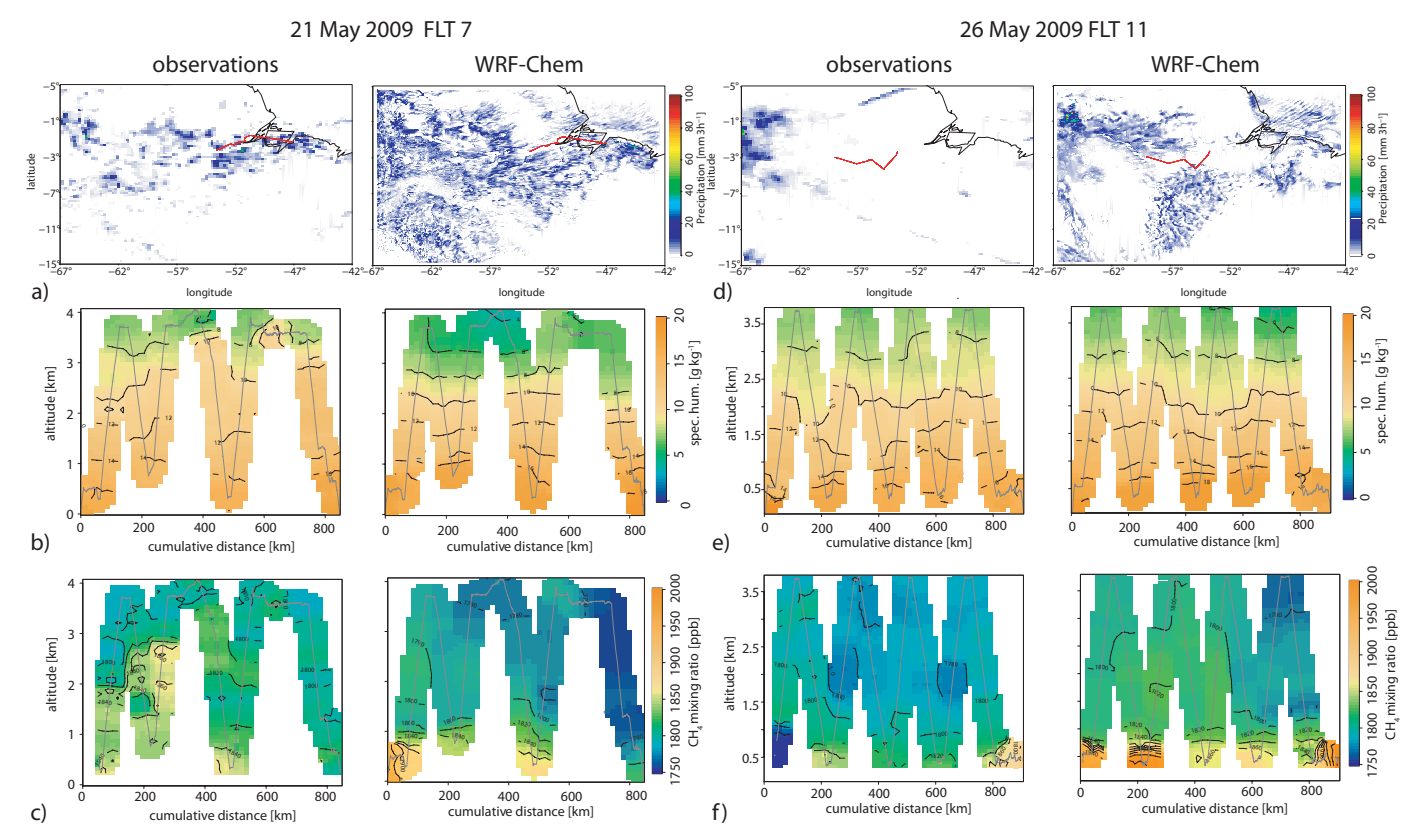

Fig. 6. Comparison between observations and WRF model output for two case studies during BARCA-B (FLT 7 from Santarém to Bélém on 21 May 2009 18:00-21:00 UTC - left panel and FLT 11 from Manaus to Santarém on 26 May 2009 13:00-16:00 UTC - right panel). On the left side of each panel the observations (TRMM for precipitation $(\mathbf{a}, \mathbf{d})$, specific humidity and $\mathrm{CH}_{4}$ from airborne observations $(\mathbf{b}$, $\mathbf{c}$, e, f)) are shown while on the right panel the WRF-GHG simulation output of WWP using the Walter wetland model and the Prigent wetland inundation map is presented.

this time almost no precipitation is found along the flight track in the 3-h time period during the flight neither in the TRMM observations nor in the WRF-Chem simulations (d). The observed and the modelled specific humidity demonstrates in both, the observations and the modelled specific humidity, more stratified layers (e) and a higher $r$-squared value $\left(r^{2}=0.944\right.$, bias $\left.=0.194 \mathrm{~K}\right)$. The modelled $\mathrm{CH}_{4}$ mixing ratio is much closer to the observed $\mathrm{CH}_{4}$ mixing ratio for this flight $\left(r^{2}=0.62\right.$, bias $\left.=23 \mathrm{ppb}\right)$, clearly indicating the higher ability of the model for the representation of the observations under more stable conditions with less convective events.
This supports the assumptions that the representation of convective events in the model along the flight track during the time of the flight has an important impact on the representation of the $\mathrm{CH}_{4}$ mixing ratio in the model.

Another difference between those two flights is the time of the day during which the flight took place. FLT 7 was conducted in the afternoon hours (18:00-21:00 UTC, 14:0017:00 LT), while FLT 11 took place in the morning hours (13:00-16:00 UTC, 09:00-12:00 LT). We compared modelled and observed $\mathrm{CH}_{4}$ mixing ratio and specific humidity of six flights on three different flight days during BARCA-B, each with one morning and one afternoon flight (excluding 
Table 4. Overview over all flights conducted during BARCA-A and BARCA-B indicated with their flight number (Flt.num), the date of each flight (Date), the flight origin and destination (direction), the number of vertical profiles flown (No. Profiles), the number of flasks sampled (No. Flasks) and rating as "good" or "bad" flights (Rating).

\begin{tabular}{|c|c|c|c|c|c|c|}
\hline & Flt.num & Date & Direction & No. Profiles & No. Flasks & Rating \\
\hline \multirow[t]{12}{*}{ BARCA-A } & 3 & 20081118 & Manaus-Santarém & 4 & 13 & "good" \\
\hline & 4 & 20081118 & Santarém-Belém & 4 & 17 & "good" \\
\hline & 5 & 20081119 & Belém-Santarém & 6 & 17 & "good" \\
\hline & 6 & 20081119 & Santarém-Manaus & 4 & 12 & "bad" \\
\hline & 7 & 20081122 & around Manaus (north) & 8 & 26 & "bad" \\
\hline & 8 & 20081123 & Manaus-Boa Vista & 8 & 14 & "bad" \\
\hline & 9 & 20081123 & Boa Vista - Manaus & 4 & 14 & "good" \\
\hline & 10 & 20081125 & Manaus - Alta Floresta & 6 & 15 & "bad" \\
\hline & 11 & 20081126 & around Alta Floresta & 8 & 14 & "bad", \\
\hline & 12 & 20081127 & Alta Floresta - Manaus & 2 & 3 & "bad" \\
\hline & 13 & 20081129 & Manaus - Tefé & 4 & 12 & "bad" \\
\hline & 14 & 20081130 & around Tefé (northwest) & 8 & 17 & "bad" \\
\hline \multirow[t]{14}{*}{ BARCA-B } & 2 & 20090517 & around Manaus (west) & 6 & 14 & "good" \\
\hline & 3 & 20090517 & around Manaus (west) & 10 & 16 & "bad" \\
\hline & 4 & 20090519 & Manaus - Boa Vista & 10 & 18 & "bad" \\
\hline & 5 & 20090519 & Boa Vista - Manaus & 6 & 12 & "bad" \\
\hline & 6 & 20090521 & Manaus - Santarém & 8 & 14 & "bad" \\
\hline & 7 & 20090521 & Santarém - Belém & 6 & 16 & "bad" \\
\hline & 8 & 20090522 & Belém offshore & 4 & 15 & "good" \\
\hline & 9 & 20090523 & Belém - Santarém & 6 & 13 & "bad" \\
\hline & 10 & 20090523 & Santarém - Manaus & 2 & 9 & "good" \\
\hline & 11 & 20090526 & Manaus - Santarém & 8 & 14 & "good" \\
\hline & 12 & 20090526 & Santarém - Manaus & 8 & 15 & "good" \\
\hline & 13 & 20090527 & Manaus - Porto Velho & 8 & 13 & "bad" \\
\hline & 14 & 20090527 & Porto Velho - Manaus & 2 & 10 & "bad" \\
\hline & 15 & 20090528 & around Manaus (city) & 2 & 13 & "good" \\
\hline
\end{tabular}

one flight because of strong convective events along the flight track). On each flight at least six vertical profiles were flown. This comparison illustrates that in general WRF-GHG shows a better representation of the specific humidity and the $\mathrm{CH}_{4}$ mixing ratio for morning flights compared to afternoon flights $\left(r_{\text {spec.hum }}^{2}=0.94\right.$ and $r_{\mathrm{CH}_{4}}^{2}=0.52$ on average for the three morning flights compared to $r_{\text {spec.hum }}^{2}=0.90$ and $r_{\mathrm{CH}_{4}}^{2}=0.33$ for the afternoon flights for WWP simulations). The other WRF-GHG simulations draw a similar picture.

\subsubsection{WRF-GHG methane simulations under different weather conditions}

To assess the impact of the atmospheric transport on the representation of the $\mathrm{CH}_{4}$ tracer mixing ratios in the model for all flights, we separated the WRF-GHG simulations in flights with good representation of the convective transport by the WRF-Chem model and those with a not so good representation, and evaluated them separately against the observations. To distinguish between "good" and "bad" flights, we compared accumulated WRF-Chem precipitation against TRMM precipitation. The precipitation pattern of TRMM was compared to that of WRF-Chem for 48-h upstream of the flight track (obtained from footprint calculations using the Stochastic Time Inverted Lagrangian Transport (STILT) model (Lin et al., 2003). A flight was rated as "good" flight when the accumulated precipitation pattern for the 48-h time-period in the upstream region of the flight track showed a similar pattern as the corresponding TRMM observations, and if additionally no strong convective event in the TRMM observations (accumulated precipitation $>30 \mathrm{~mm}$ during the $3-\mathrm{h}$ flight period) in $200 \mathrm{~km}$ surroundings of the flight track was found during the 3-h time-period of the flight. For BARCAA, the flights 3,4,5,9 have been rated as "good" flights, while for BARCA-B the flights $2,9,10,11,12,15$ could be rated as "good" flights. Table 4 demonstrates an overview of flight destination, flight origin, and rating of each single flight during BARCA-A and BARCA-B.

Figure 7 presents a normalised Taylor diagram (Taylor, 2001) separating between "good" (Fig. 7a, c) and "bad" (Fig. 7b, d) flights of both campaigns (BARCA-A flasks black symbols, BARCA-B flasks - darkblue symbols, and BARCA-B continuous observations - gold symbols). Additionally for each case the comparison is evaluated separately at all flight altitudes $(\mathrm{a}, \mathrm{b})$ and in the planetary boundary layer 

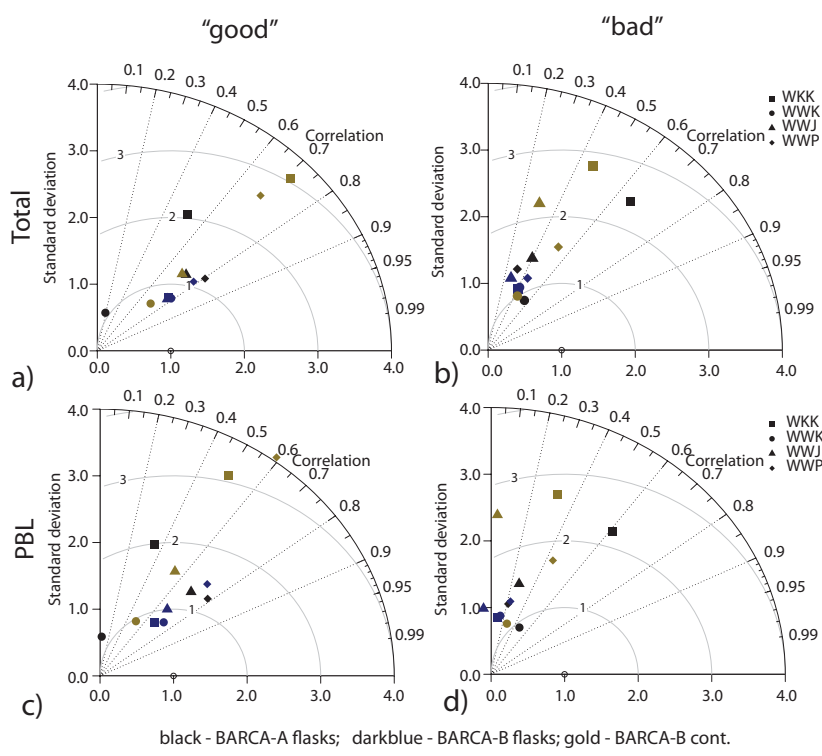

Fig. 7. Taylor diagram illustrating the normalised standard deviation and the Pearson's correlation coefficient for the comparison of the total $\mathrm{CH}_{4}$ mixing ratio of the different WRF simulations (BARCAA flasks - black; BARCA-B flasks - darkblue; BARCA-B cont. observations - gold). They are divided into flights with good weather conditions (a, c) and bad weather conditions (b, d). Additionally, they are separated in observations at all altitudes $(\mathbf{a}, \mathbf{b})$ and observations in the planetary boundary layer (altitudes $<1250 \mathrm{~m}$ ) only (c, d).

(c, d). The wetland emissions are not adjusted for this comparison.

Comparing the correlations of the model output with the observations at all altitudes of all three datasets (BARCAA flasks, BARCA-B flasks, BARCA-B continuous observations) for "good" and the "bad" flights (Fig. 7a-b), a substantial higher correlation is notable for the "good" flights during BARCA-B ( $r=0.77-0.79$ for flasks and $r=0.69-0.72$ for continuous observations) compared to the "bad" flights ( $r=0.28-0.44$ for flasks and $r=0.30-0.53$ for continuous observations). For BARCA-A, at first glance the difference in the ability of the WRF-GHG model in capturing the variances of the observed $\mathrm{CH}_{4}$ mixing ratios seems not to be dependent on the quality of the representation of the atmospheric transport. However, for WWJ and WWP the variability explained by the model for the "good" rated flights is substantially higher compared to the "bad" rated flights $(r=0.73$ and 0.80 compared to $r=0.40$ and 0.31 , respectively), which is not the case for the two WRF-GHG simulations using the Kaplan wetland inundation map. Exploring the location of the four "good" rated flights during BARCA-A, it can be seen that three of them (Flights 3,4,5) took place in the eastern part of the Amazon region. This leads to the assumption that the Kaplan wetland inundation might not represent the inundated area in the eastern part of the Amazon properly (see also Sect. 4.3.4).

In general, the correlation taking model output at all altitudes into account is higher than considering the planetary boundary layer only for all three observation types. This indicates that the model more easily captures the gradient in the $\mathrm{CH}_{4}$ mixing ratio between the planetary boundary layer and the free troposphere than the spatial and temporal patterns within the planetary boundary layer.

It leads to the conclusion that during both, BARCA-A and BARCA-B, the representation of the variances depends also on the weather conditions, both the weather conditions during the 48-h time period upstream of the flight track and during the $3 \mathrm{~h}$ time period of the flight itself. The WRF-GHG model has a greater ability to capture variances in the $\mathrm{CH}_{4}$ mixing ratio, if the convective transport is represented properly.

\subsubsection{Adjustment of wetland fluxes}

As the calculated $\mathrm{CH}_{4}$ emissions from the bottom-up models (here: KWM and WWM) depend on the driving meteorology and the choice of wetland inundation map, the $\mathrm{CH}_{4}$ emissions from wetlands have been adjusted for all four WRF-GHG simulations for the Amazon basin. As the reference period for the adjustment, the simulation period of May 2009 was selected. Due to almost no biomass burning activity during that time period and given that emissions from anthropogenic and other smaller sources are rather constant throughout the year, the only varying source component are $\mathrm{CH}_{4}$ emissions from wetlands. To reduce the impact of an improper representation of the atmospheric transport on the simulated tracer distribution, only those flights with a "good" rating during BARCA-B (cf. Table 4) were included in the adjustment. FLT 8 was not included as the flight track is mainly located over the Atlantic Ocean. The tagged tracer analysis of the four WRF-GHG simulations for all other "good" rated flights results in a mean wetland contribution of $91 \%$. To calculate the adjustment factor for the $\mathrm{CH}_{4}$ emissions from wetlands, the model simulations of the corresponding flights were sampled at the time and location of the BARCA-B observations for all $\mathrm{CH}_{4}$ tagged tracers in WRF-GHG. The $\mathrm{CH}_{4}$ wetland fluxes from the different simulations (WKK, WWK, WWJ, and WWP) were each adjusted by a single scaling factor, such that the simulated $\mathrm{CH}_{4}$ mixing ratios matched the observed mixing ratios for all flights rated as "good", i.e. those flights where convective precipitation was either small or where simulated precipitation was similar to observed precipitation. The adjustment (see Table 3) uses observations within the planetary boundary layer and in the lower free troposphere. Although all observations are equally weighted, the absolute number of the scaling factors is mainly driven by the values in the planetary boundary layer. The adjustment is considered to be representative for most of the BARCA-B flights as the western, central, and eastern regions have been fully covered. As the same scaling factors for each wetland $\mathrm{CH}_{4}$ emission model were 

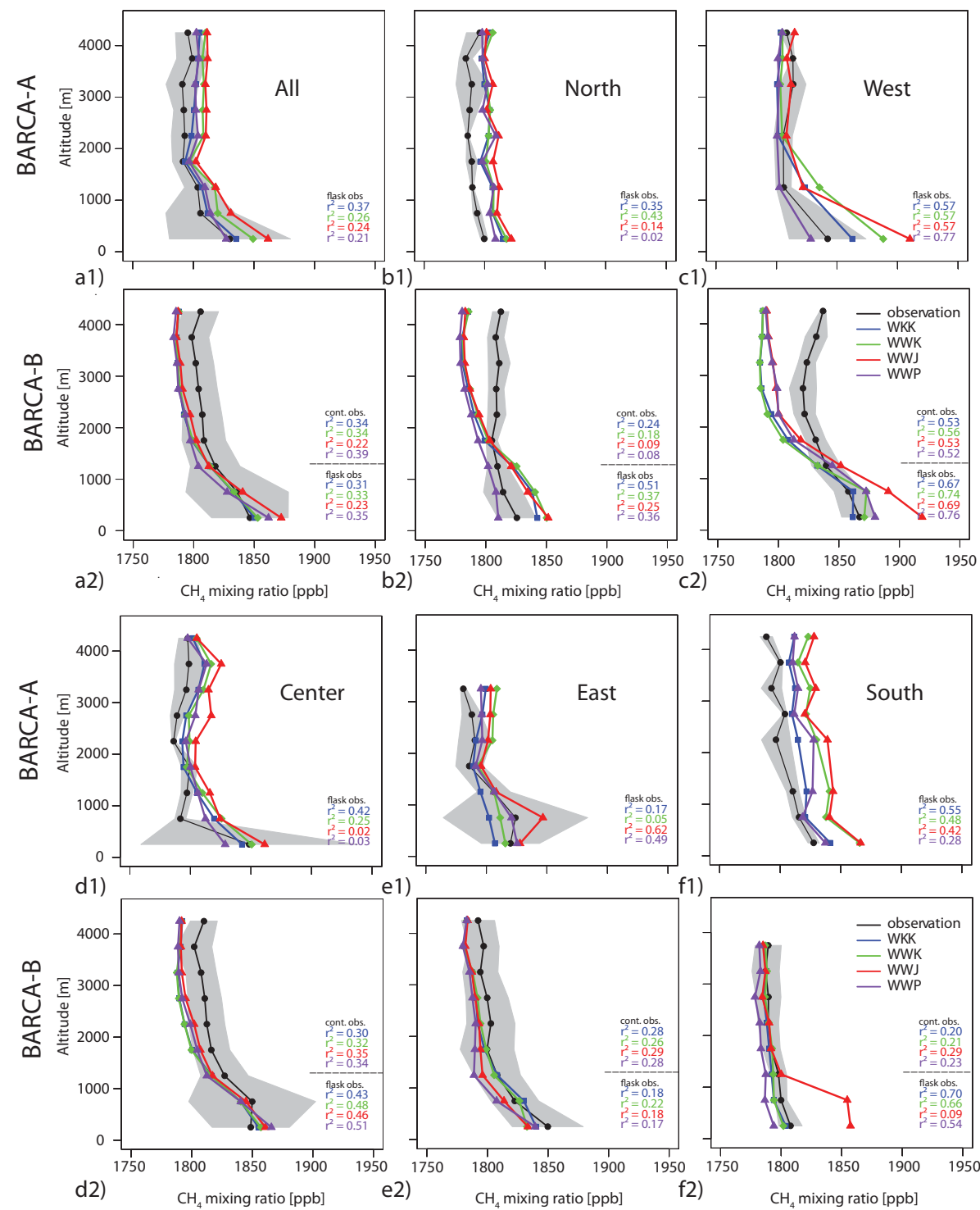

Fig. 8. Comparison of BARCA-A (1) and BARCA-B (2) observations (black) to different WRF simulations with adjusted wetland component (WKK - blue; WWK - green; WWJ - red; WWP - violet) binned in $500 \mathrm{~m}$ vertical profiles for five different region of the Amazon basin. The regions are defined as follows: (a) north: latitude $>-1.0^{\circ}$ and longitude $>-62.0^{\circ}$ (b) west: latitude $>-5.0^{\circ}$ and longitude $<-62.0^{\circ}$ (c) central: latitude $>-5.0^{\circ}$ and latitude $<-1.0^{\circ}$ and longitude $>-62.0^{\circ}$ and longitude $<-58.0^{\circ}$ (d) east: latitude $>-5.0^{\circ}$ and latitude $<0.0^{\circ}$ and longitude $>-58.0^{\circ}$ (e) south: latitude $<-5.0^{\circ}$.

also applied to the BARCA-A simulations during November 2008, the model skills to describe seasonal changes can be assessed.

In the first simulation (WKK), the $\mathrm{CH}_{4}$ wetland emissions have been calculated online using KWM in combination with the Kaplan wetland inundation map. The $\mathrm{CH}_{4}$ wetland emissions calculated by KWM have been reduced by $76 \pm 4 \%$ for November 2008 and May 2009. The second simulation (WWK) uses WWM together with the Kaplan wetland inundation map to allow for a direct comparison of the two wetland models. For WWK, the $\mathrm{CH}_{4}$ wetland emissions are increased by $9 \pm 21 \%$ for both months. In WWJ, WWM in combination with the JERS-1SAR wetland inundation map is utilised with reduced $\mathrm{CH}_{4}$ wetland emissions of $27 \pm 16 \%$. Finally, in the fourth simulation (WWP) WWM in combination with the Prigent wetland inundation map was selected. The $\mathrm{CH}_{4}$ wetland emissions of WWP have been reduced by $55 \pm 12 \%$. Uncertainties of the scaling factors have been calculated in the following way: as the scaling factors are derived as a ratio of two terms, the observation based wetland contribution (observed $\mathrm{CH}_{4}$ mixing ratio minus the sum of simulated contributions from all other sources and the background) and the modelled wetland contribution, the statistical uncertainties of each term was propagated, taking into 
account that the time series are auto-correlated (the number of degrees of freedom is less than the number of individual data points). Resulting uncertainties range from 4 to $21 \%$ for the different simulations. Table 3 summarises all details.

An evaluation of the separate $\mathrm{CH}_{4}$ tracers for all different flux components within the WRF-GHG simulations demonstrates that the contributions of $\mathrm{CH}_{4}$ emissions from termites and $\mathrm{CH}_{4}$ uptake by soils are negligible compared to the three main sources, namely as $\mathrm{CH}_{4}$ emissions from wetlands, biomass burning, and other anthropogenic sources (not shown).

\subsubsection{Comparison to BARCA $\mathrm{CH}_{4}$ observations with adjusted wetland fluxes}

Figure 8 illustrates vertical profiles of the observations (black) and the four WRF-GHG simulations (WKK - blue, WWK - green, WWJ - red, and WWP - blueviolet) during both campaigns for all observations of the BARCA-A and BARCA-B campaigns, and separated into five different sampling regions. The profiles are binned into $500-\mathrm{m}$ vertical intervals. The $r$-squared value is calculated prior to binning into $500 \mathrm{~m}$ vertical intervals for all observations and model values in that sampling region. For both campaigns, $r$-squared values of the comparison between flask observations and the corresponding model values are given, while for BARCA-B also the $r$-squared values of the comparison to the continuous observations (not including flights $8-10$ ) are calculated as well.

During BARCA-A, the comparison of the campaign averaged vertical profile of the four different WRF-GHG simulations with the observations (Fig. 8a1) illustrates that all combinations of different wetland models and wetland inundation maps are able to reproduce the vertical structure of the campaign averaged profile of the observations. This is indicated by a fairly constant bias between model simulations and observations for the total profile (6-18 ppb), which does not change substantially when calculating the bias separately for the planetary boundary layer (4-24 ppb) and the free lower troposphere (7-16 ppb). The situation changes for BARCA-B (Fig. 8a2). Here all simulations have difficulties in reproducing the vertical structure of the campaign averaged profile. It results in a smaller overall bias compared to BARCA-A ( -6 to $-11 \mathrm{ppb}$ ) due to the binning into $500 \mathrm{~m}$ height intervals. However, when splitting the bias calculation into a planetary boundary layer and a lower free troposphere part ( -2 to $8 \mathrm{ppb}$ vs. -12 to $-16 \mathrm{ppb})$, it is clear that the models are not able to capture the vertical structure of the observations, but have especially a high bias in the lower free troposphere.

In the next step, we evaluate the WRF-GHG simulations against observations in five different regions of the Amazon basin separately for BARCA-A and BARCA-B starting with BARCA-A.
In the northern and central part during BARCA-A (Fig. 8b1), all simulations denote a constant bias of the total vertical profile compared to the observations (7-19 ppb). The structure of the vertical profile of the observations in the western part during BARCA-A (Fig. 8c1) is captured well, however most of the models tend to overestimate the observations in the planetary boundary layer ( -9 to $42 \mathrm{ppb}$ ). In the eastern part (Fig. 8e1), the model simulations show a slight overestimation in the free troposphere $(8-16 \mathrm{ppb})$ and a range of -11 to $15 \mathrm{ppb}$ in the planetary boundary layer. In the southern part, all models overestimate the observations of the total vertical profile during BARCA-A by $13-32 \mathrm{ppb}$ (Fig. 8f1). This can be partially traced back to too high $\mathrm{CH}_{4}$ emissions from biomass burning as the tagged tracers indicate that emissions from biomass burning are either the dominating source of $\mathrm{CH}_{4}$ (WWP) or of the same magnitude as the wetland emissions in that region (WKK, WWK, and WWJ). Given that a comparison of simulated with observed $\mathrm{CO}$ during the same campaign indicates close agreement and suggests that biomass burning emissions of $\mathrm{CO}$ are fully consistent with the atmospheric constraint (Andreae et al., 2012), this might point to an overestimation of emission factors for $\mathrm{CH}_{4}$. For the WWP simulation, a reduction of the biomass burning emissions by a factor of two would be required to match the observations.

For BARCA-B, similar to the total vertical profile, the simulations tend to underestimate the observations in the lower free troposphere $(-13$ to $-36 \mathrm{ppb})$ and to overestimate the observations in the planetary boundary layer $(-10$ to $32 \mathrm{ppb}$ ) in the northern, central, and western part. Interestingly, the observations in the western part during BARCA-B show high values up to $1850 \mathrm{ppb}$ at $4000 \mathrm{~m}$ altitude, which have not been observed in other regions of the Amazon basin. Backward calculations using the STILT model indicate that most of the air at $3000-4000 \mathrm{~m}$ altitude in that region originates from the northwestern part of the Amazon. For this region also observations from SCIAMACHY suggest high $\mathrm{CH}_{4}$ emissions (Frankenberg et al., 2006, 2011). This potential source region might not be properly represented in the flux distribution of the outer domain (d01), leading to an additional underestimation of the observations in the lower free troposphere besides vertical mixing. The structure of the vertical profile of the observations in the eastern part during BARCA-B (Fig. 8e2) is reproduced well by all of the models with slight underestimation of the total vertical profile, resulting in biases of -6 to $-13 \mathrm{ppb}$. The observations in the southern part during BARCA-B (Fig. 8f2) show a bias of -10 to $12 \mathrm{ppb}$ on the total vertical profile.

As a last step the differences between the four model simulations (WKK, WWK, WWJ, and WWP) are discussed for the five different regions of the Amazon basin. If not explicitly stated, we use the continuous observations for BARCA$\mathrm{B}$ for the comparison (in addition the flask samples for BARCA-A). 
For BARCA-A and BARCA-B WKK and WWK seem to capture the variances better in the northern sampling region $\left(r^{2}=0.39-0.47\right.$ (BARCA-A) and $r^{2}=0.18-0.26$ (BARCAB), Fig. 8b1-b2) compared to WWJ and WWP $\left(r^{2}=0.02-\right.$ 0.14 (BARCA-A) vs. $r^{2}=0.08-0.09$ (BARCA-B)). This is also true for the central region during BARCA-A. In Fig. 2b4-b5, the Kaplan wetland inundation map shows higher values in the northern part of the nested domain compared to the Prigent wetland inundation map for both months, while the JERS-1SAR wetland inundation map also predicts high fraction of inundation values for the northern part (Fig. 2b1). However, calculated backward trajectories from the STILT model also indicate contributions of the northwestern part of South America for the northern part of the Amazon region, an area where the Kaplan wetland inundation map depicts a wider spread area with a higher fraction of inundation (not shown). This leads to the conclusion that the Kaplan wetland map represents the inundated area in the northern and central part of the Amazon and the South American continent better than the other two wetland inundation maps.

Considering the western part, the variances of the observations are captured well by all WRF-GHG simulations $\left(r^{2}\right.$ between 0.57 and 0.77 ) for both campaigns (Fig. 8c1-c2). For BARCA-A, WKK, WWK, and WWJ overestimate the observations in the planetary boundary layer between 19 and $42 \mathrm{ppb}$. Only WWP slightly underestimates the observations (bias of the total vertical profile $-8 \mathrm{ppb}$ ). Compared to the other wetland inundation maps, the Prigent wetland inundation map shows lower inundated area right beneath the flight track for the western Amazon flights (cf. Fig. 2a1-a3). For BARCA-B, the relatively high $r^{2}$ of $0.52-0.56$ for all four model simulations should not hide the fact that the representation of the vertical structure of the observations for all simulations is worse in this region compared to all other regions as discussed above. The global TM5 inversions on $6^{\circ} \times 4^{\circ}$ horizontal resolution (cf. Beck et al., 2012) using additional constraints on the a-posteriori fluxes from SCIAMACHY observations, are able to represent the structure of the vertical profile better compared to the WRF-GHG simulations.

In the eastern part, during BARCA-A the WRF-GHG simulations of WWJ and WWP seem to capture the variances better compared to WKK and WWK (Fig. 8e1; $r^{2}=0.49$ 0.62 vs. $r^{2}=0.05-0.17$, respectively), which points to an underestimation of the inundated area in the Kaplan wetland inundation map in that region (cf. Figure 2a1-a3). In contrast to TM5 inversions (Beck et al., 2012), the high resolution WRF-GHG simulations were able to capture the higher $\mathrm{CH}_{4}$ mixing ratios in that regions during BARCA-A. During BARCA-B (Fig. 8e2), all WRF-GHG simulations show relatively low $r$-squared values for the eastern part $\left(r^{2}=0.27-\right.$ 0.29 ), which could partially be explained by strong convective events that took place in this area during the flight days which are more difficult for the model to represent.
During BARCA-B, all WRF-GHG simulations in the southern part except for WWJ show high $r^{2}$ especially compared to the flask observations ( $r^{2}$ ranging from 0.56 to 0.73 and $r^{2}=0.09$ for WWJ). WWJ denotes a too high $\mathrm{CH}_{4}$ mixing ratio in the planetary boundary layer in that sampling region. A closer look on the wetland inundation map in Fig. $2 \mathrm{a} 2$ and $\mathrm{b} 1-\mathrm{b} 3$ indicates that the JERS-1SAR wetland inundation map shows a greater inundated area around $60^{\circ} \mathrm{W}$ and $9^{\circ} \mathrm{S}$, which cannot be found in the other wetland maps. A comparison of different cross-sections depicts high emissions on about $70 \%$ of the total flown distance of that flight, coinciding very well with the location of the inundated area described above.

In general, the $r$-squared values when using only the flask observations are higher than using continuous observations during BARCA-B (cf. Figs. 7 and 8). This is due to the fact that the flask samples are already collected in a way (one/two samples in the planetary boundary layer and one/two samples in the free troposphere per flown profile) that they favour the explanation of the variances by the model more than the continuous observations which report a data point each three seconds (Chen et al., 2010).

From the comparison of the four WRF-GHG simulations utilising two different wetland models and three different wetland inundation maps, we conclude that the Kaplan wetland inundation map represents the wetland area in the northern part of the Amazon basin and around the Manaus area during both months November and May best, while the Prigent wetland inundation map has the best representation in the western and eastern part of the Amazon basin during BARCA-A. This favours at least for those regions a wetland inundation map with inundated area changing in time during the dry season. From comparison with the aircraft observations, we conclude that the choice of the wetland inundation map that defines the distribution of the inundated areas is more important than the choice of the wetland model.

The explained variability $\left(r^{2}\right)$ of the high-resolution WRFGHG simulations compared to the global TM5-based $\mathrm{CH}_{4}$ inversions (cf. Beck et al., 2012) was found to be substantially larger only for the western and eastern region during BARCA-A. This underlines the importance of a proper representation of the atmospheric transport in regional atmospheric transport models when they are applied in tropical regions. It further emphasises the need for a wetland inundation map at high horizontal and monthly temporal resolution that adequately represents the inundated wetland area throughout the complete Amazon basin as the monthly temporal resolution of the inundated wetland area is, e.g. already implicitly included in the global TM5 inversions. With these two requirements, additional benefits from the usage of regional atmospheric transport models can be achieved. 
Table 5. Calculation of the total $\mathrm{CH}_{4}$ budget numbers $\left[\mathrm{Tg} \mathrm{mol}^{-1}\right]$ and the wetland contributions of the four different WRF-GHG simulations for the Amazon lowland and Amazon mainstream region (see text).

\begin{tabular}{|c|c|c|c|c|c|c|}
\hline & \multicolumn{3}{|c|}{ Amazon lowland } & \multicolumn{3}{|c|}{ Amazon mainstream area } \\
\hline & $\begin{array}{l}\text { Total } \\
\text { budget } \\
{\left[\mathrm{Tg} \mathrm{mol}^{-1}\right]}\end{array}$ & $\begin{array}{l}\text { Wetland } \\
\text { contribution } \\
{\left[\mathrm{Tg} \mathrm{mol}^{-1}\right]}\end{array}$ & $\begin{array}{l}\text { Average } \\
\text { total flux } \\
{\left[\mathrm{mg} \mathrm{m}^{-2} \mathrm{~d}^{-1}\right]}\end{array}$ & $\begin{array}{l}\text { Total } \\
\text { budget } \\
{\left[\mathrm{Tg} \mathrm{mol}^{-1}\right]}\end{array}$ & $\begin{array}{l}\text { Wetland } \\
\text { contribution } \\
{\left[\mathrm{Tg} \mathrm{mol}^{-1}\right]}\end{array}$ & $\begin{array}{l}\text { Average } \\
\text { total flux } \\
{\left[\mathrm{mg} \mathrm{m}^{-2} \mathrm{~d}^{-1}\right]}\end{array}$ \\
\hline \multicolumn{7}{|c|}{ BARCA-A: } \\
\hline WKK & 2.2 & 1.6 & 14 & 0.9 & 0.8 & 17 \\
\hline WWK & 4.8 & 4.2 & 31 & 1.8 & 1.7 & 34 \\
\hline WWJ & 4.8 & 4.2 & 31 & 1.8 & 1.7 & 34 \\
\hline WWP & 1.5 & 0.9 & 9 & 0.8 & 0.7 & 15 \\
\hline \multicolumn{7}{|c|}{ BARCA-B: } \\
\hline WKK & 3.0 & 2.6 & 19 & 1.4 & 1.3 & 25 \\
\hline WWK & 3.5 & 3.1 & 22 & 1.4 & 1.3 & 27 \\
\hline WWJ & 5.5 & 5.1 & 36 & 2.1 & 2.0 & 39 \\
\hline WWP & 1.3 & 0.9 & 8 & 0.6 & 0.7 & 13 \\
\hline
\end{tabular}

\subsection{Amazon region budget calculations}

After the evaluation of the WRF-GHG simulations against the BARCA observations, we now present the calculated $\mathrm{CH}_{4}$ budgets for these forward simulations with an already adjusted wetland flux component. The budgets are determined for the 5.19 million square kilometre area of the Amazon lowland region (cf. dashed line Fig. 1) and the 1.77 million square kilometre area of the Amazon mainstream from $-8^{\circ} \mathrm{S}$ to $0^{\circ} \mathrm{S}$ and $-72^{\circ} \mathrm{W}$ to $-54^{\circ} \mathrm{W}$. Both regions are defined and described in Melack et al. (2004). Table 5 illustrates the results for the monthly $\mathrm{CH}_{4}$ budgets in detail.

The total monthly $\mathrm{CH}_{4}$ budgets from the four different WRF-GHG simulations for the Amazon lowland region range from 1.5 to $4.8 \mathrm{Tg}$ for November 2008 and from 1.3 to $5.5 \mathrm{Tg}$ for May 2009. The $\mathrm{CH}_{4}$ emissions from wetlands are the dominating source both in November 2008 and in May 2009 (cf. Table 5). The $\mathrm{CH}_{4}$ biomass burning flux contributes $0.27 \mathrm{Tg}$ in November 2008 and $0.04 \mathrm{Tg}$ in May 2009, while the contribution of other anthropogenic sources is similar in both months $(\sim 0.12 \mathrm{Tg})$. This implies average total $\mathrm{CH}_{4}$ fluxes of $9-31 \mathrm{mg} \mathrm{m}^{-2} \mathrm{~d}^{-1}$ for November 2008 and 8$36 \mathrm{mg} \mathrm{m}^{-2} \mathrm{~d}^{-1}$ for May 2009. Furthermore, it indicates that besides the biomass burning emissions and slightly higher wetland emissions during BARCA-B (on average $2.7 \mathrm{Tg}$ vs. $3.3 \mathrm{Tg}$ ), no substantial change in the source contributions between November 2008 and May 2009 is notable. Even though the wetland source was adjusted for all four WRFGHG simulations, the wetland contributions for the total Amazon lowland area draw a highly variable picture. For this region, the combination of the Walter wetland model and the Prigent wetland inundation map led to the lowest wetland emissions $(0.9 \mathrm{Tg}$ for both month) while using the same wetland model, but the JERS-1SAR wetland inunda- tion map instead produced the highest wetland emissions (4.2 Tg for November 2008 and 5.2 Tg for May 2009). WWK is the only simulation that shows a substantial higher wetland contribution in November 2008 (4.2 Tg) compared to May $2009(3.1 \mathrm{Tg})$. All other simulations have either similar or smaller wetland contributions in November 2008 compared to May 2009 (cf. Table 5). As two other simulations utilising the same wetland model WWM as the WWK simulation (WWJ and WWP) have a higher wetland contribution in May 2009 compared to November 2008, the explanation has to be traced back to differences in the wetland inundation maps. The Kaplan wetland inundation map utilised for the WWK simulations contains substantially more wetland grid points in the northwestern Amazon compared to the JERS-1SAR and Prigent wetland inundation map. In this area WWM calculates a considerable higher $\mathrm{CH}_{4}$ flux for November 2008 compared to KWM.

This indicates that our method of using one scaling factor for the entire Amazon basin shows no sensitivity to different regions. The results might change by adding information on the bias for the different regions as it could be conducted, e.g. by a regional inversion with spatial flexibility in adjusting fluxes and flux patterns. It further clearly demonstrates that the BARCA observations do not put on an observational constraint for the entire Amazon lowland region, especially not for the western part.

For the Amazon mainstream area, which was covered to a higher percentage by the BARCA flights, the calculated budget numbers range from 0.8 to $1.8 \mathrm{Tg}$ for November 2008 and from 0.8 to $2.1 \mathrm{Tg}$ for May 2009. The average total calculated $\mathrm{CH}_{4}$ flux to the atmosphere here is higher (15$35 \mathrm{mg} \mathrm{m}^{-2} \mathrm{~d}^{-1}$ for November 2008 and $13-39 \mathrm{mg} \mathrm{m}^{-2} \mathrm{~d}^{-1}$ for May 2009) compared to the Amazon lowland. Also for this area the simulation using the Prigent wetland inundation 
map has the lowest budget number compared to the other simulations (e.g. $0.8 \mathrm{Tg}$ vs. to $1.4-2.1 \mathrm{Tg}$ for May 2009). This leads to the assumption that even though the Prigent wetland inundation map performed very well in capturing the variability along the flight path, it might underestimate the wetland area, e.g. in flooded forest areas further away from the open waters of the Amazon river (cf. number of wetland grid points in the d02 domain in Table 3 and total inundated wetland area in Fig. 2).

The average of the calculated budgets of the four WRFGHG simulations of the Amazon lowland region is lower $(3.3 \pm 0.8 \mathrm{Tg}$ for November 2008 and $3.3 \pm 0.9 \mathrm{Tg}$ for May 2009) compared to the budget estimates obtained from the comparison of TM5-based global $\mathrm{CH}_{4}$ inversions and the BARCA observations $(5.7 \pm 0.7 \mathrm{Tg}$ for November 2008 and $6.9 \pm 1.1 \mathrm{Tg}$ for May 2009) as described in Beck et al. (2012). However, when not considering the simulation using the Prigent wetland inundation map (WWP), the average of the calculated WRF-GHG budgets is substantially higher $(3.9 \pm 0.8 \mathrm{Tg}$ for November 2008 and $4.0 \pm 0.8 \mathrm{Tg}$ for May 2009) and closer to the budget numbers derived by Beck et al. (2012). The calculated monthly $\mathrm{CH}_{4}$ budgets for November 2008 and May 2009 show similar numbers. However, when taking into account the constant bias of the vertical profile during BARCA-A (7-18 ppb), the budget that would match the observations perfectly for November 2008 would be lower, which would be more in accordance with the expected higher wetland emissions in May compared to November (Devol et al., 1990).

Melack et al. (2004) estimated the yearly contribution of wetland $\mathrm{CH}_{4}$ emissions in the Amazon lowland region to $29.3 \mathrm{Tg}$, corresponding to a monthly average of $2.4 \mathrm{Tg}$. The monthly wetland contribution of WWP for November 2008 and May 2009 is roughly one third of that estimated by Melack et al. (2004), while the wetland contribution of almost all other simulations is substantially higher than $2.4 \mathrm{Tg}$ for both months, November 2008 and May 2009. For the Amazon mainstream area, Melack et al. (2004) estimated the yearly $\mathrm{CH}_{4}$ contributions from wetlands to be $9 \mathrm{Tg}$ (corresponding to $0.75 \mathrm{Tg} \mathrm{mol}^{-1}$ assuming an equal distribution over the whole year). In this region, all WRF-GHG simulations show a higher monthly $\mathrm{CH}_{4}$ wetland contribution ranging from 0.7 to $2.1 \mathrm{Tg}$.

Miller et al. (2007) calculated flux estimates for the Amazon region based on the difference in the mixing ratios between the NOAA-ESRL background stations in Ragged Point Barbados (BDS) and Ascension Island (UK) and vertical airborne profiles over Manaus and Santarém. They estimated a $\mathrm{CH}_{4}$ flux of $35 \mathrm{mg} \mathrm{m}^{-2} \mathrm{~d}^{-1}$ for the Santarém area and $20 \mathrm{mg} \mathrm{m}^{-2} \mathrm{~d}^{-1}$ for the Manaus area, which is in good agreement with our obtained flux estimates from the WRFGHG simulations (15-34 $\mathrm{mg} \mathrm{m}^{-2} \mathrm{~d}^{-1}$ for November 2008 and $13-39 \mathrm{mg} \mathrm{m}^{-2} \mathrm{~d}^{-1}$ for May 2009) for the Amazon mainstream.
Summarising the comparison of the WRF-GHG $\mathrm{CH}_{4}$ budgets to previous budget estimates for the Amazon region, we conclude that $\mathrm{CH}_{4}$ budget estimates using the atmospheric constraint (this paper; Miller et al., 2007; Beck et al., 2012) up to now lead to a higher $\mathrm{CH}_{4}$ budget of the Amazon region compared to the bottom-up estimate as described in Melack et al. (2004).

\section{Conclusions}

Our evaluation demonstrated that choice of the wetland inundation map for simulating $\mathrm{CH}_{4}$ transport of the Amazon basin is of high impact, much more that the choice of the model for the calculation of the $\mathrm{CH}_{4}$ emissions from anaerobic production in wetlands itself. However, before scaling the wetland emission to be consistent with observed mixing ratios, the covered range in emissions using different wetland models with the same wetland inundation map was about $30 \%$ higher compared to the range in emissions using different wetland inundation maps. When emissions are scaled to match the atmospheric observations, both wetland models were found to represent the $\mathrm{CH}_{4}$ flux from anaerobic microbial production in wetlands according to the literature values. For the northern part of the Amazon and the Manaus area, the $\mathrm{CH}_{4}$ emissions using the Kaplan wetland inundation map showed the best agreement to the observations, while during BARCA-A only, the wetland inundation map of Prigent was found to have the best agreement to the observations in the western and eastern part. This favours (except for the northern part) the assumption that a wetland inundation map with inundated area changing in time could improve the agreement with the observations. Furthermore, a regional inversion with spatial flexibility in adjusting fluxes and flux patterns could lead to substantial improvements here. Additional observations in the western part of the Amazon basin are essential for improved constraints on the wetland emissions in the entire Amazon lowland region.

We demonstrated that the WRF-Chem model represents the observations better during days with less convection during the $48 \mathrm{~h}$ before the flight in the upstream area. The substantial decrease in model performance for flights with stronger convective activity (about half of the total number of flights) suggests that vertical transport by convection has a major impact on the distribution of atmospheric $\mathrm{CH}_{4}$ in the Amazon, and that the transport model used for this study inadequately represent this process. Thus, improvements in representing the challenging meteorological conditions and thus, of atmospheric transport models are required, in order to constrain flux estimates properly and obtain more stable budget numbers. We regard this as an essential step that needs to be taken before using such transport models for regional scale inverse estimates. 
Acknowledgements. We are very thankful to the complete BARCA team including E. Gottlieb, V. Y. Chow, M. D. P. Longo, G. W. Santoni, S. C. Wofsy, K. T. Wiedemann, P. Artaxo, F. Morais, A. C. Ribeiro, N. Juergens, M. O. Andreae, J. Steinbach, H. Chen, O. Kolle, L. V. Gatti, J. B. Miller, and the two pilots of the INPE Bandeirante airplane P. Celso and D. Gramacho for conduction two successful campaigns and collecting the data. We thank Armin Jordan and Stephan Baum for their contribution to the flask analysis. D. Pillai, R. Ahmadov, R. Kretschmer for assisting in setting up the WRF-Chem model framework and fruitful discussions about the topic. This work was supported by the Max Planck Society. Funding for the BARCA flights was provided by Max Planck Society, NASA through the grants NASA NNX08AP68A and NASA NNX10AR75G, the CNPq Millennium Institute of the Large Scale Biosphere - Atmosphere Experiment in Amazonia (LBA) and FAPESP. We thank INPA (Instituto Nacional de Pesquisas da Amazonia) for the support for the LBA central office.

The service charges for this open access publication have been covered by the Max Planck Society.

Edited by: L. Ganzeveld

\section{References}

Ahmadov, R., Gerbig, C., Kretschmer, R., Koerner, S., Neininger, B., Dolmann, A. J., and Sarat, C.: Mesoscale covariance of transport and $\mathrm{CO}_{2}$ fluxes: Evidence from observations and simulations using the WRF-VPRM coupled atmosphere-biosphere model, J. Geophys. Res., 112, D22107, doi:10.1029/2007JD008552, 2007.

Ahmadov, R., Gerbig, C., Kretschmer, R., Körner, S., Rödenbeck, C., Bousquet, P., and Ramonet, M.: Comparing high resolution WRF-VPRM simulations and two global $\mathrm{CO}_{2}$ transport models with coastal tower measurements of $\mathrm{CO}_{2}$, Biogeosciences, 6, 807-817, doi:10.5194/bg-6-807-2009, 2009.

Alonso, M. F., Longo, K. M., Freitas, S. R., da Fonseca, R. M., Marécal, V., Pirre, M., and Klenner, L. C.: An urban emission inventory for South America and its application in numerical modeling of atmospheric chemical composition at local and regional scales, Atmos. Environ., 44, 5072-5083, 2010.

Andreae, M. O., Artaxo, P., Beck, V., Bela, M., Freitas, S., Gerbig, C., Longo, K., Munger, J. W., Wiedemann, K. T., and Wofsy, S. C.: Carbon monoxide and related trace gases and aerosols over the Amazon Basin during the wet and dry seasons, Atmos. Chem. Phys., 12, 6041-6065, doi:10.5194/acp-12-6041-2012, 2012.

Bartlett, K. B., Crill, P. M., Sebacher, D. I., Harriss, R. C., Wilson, J. O., and Melack, J. M.: Methane Flux From the Central Amazonian Floodplain, J. Geophys. Res., 92, 1571-1582, 1988.

Bartlett, K. B., Crill, P. M., Bonassi, J. A., Richey, J. E., and Harriss, R. C.: Methane Flux From the Amazon River Floodplain: Emission During Rising Water, J. Geophys. Res., 95, 773-788, 1990.

Beck, V.: Determination of methane budget of the Amazon region utilising airborne methane observations in combination with atmospheric transport and vegetation modelling, Dissertation, Friedrich-Schiller-Universität Jena, 226 pp., 2012.
Beck, V., Koch, T., Kretschmer, R., Marshall, J., Ahmadov, R., Gerbig, C., Pillai, D., and Heimann, M.: The WRF Greenhouse Gas Model (WRF-GHG), Technical Report No. 25, Max Planck Institute for Biogeochemistry, Jena, Germany, available online at: http://www.bgc-jena.mpg.de/bgc-systems/index.shtml, 2011.

Beck, V., Chen, H., Gerbig, C., Bergamaschi, P., Bruhwiler, L., Houweling, S., Röckmann, T., Kolle, O., Steinbach, J., Koch, T., Sapart, C., Van der Veen, C., Frankenberg, C., Andreae, M. O., Artaxo, P., Longo, K. M., and Wofsy, S. C.: Methane airborne measurements and comparison to global models during BARCA, J. Geophys. Res., 117, doi:10.1029/2011JD017345, 2012.

Belward, A.: The IGBP-DIS global $1 \mathrm{~km}$ land cover data set (DISCover)-proposal and implementation plans, IGBP-DIS Working Paper No. 13, Toulouse, France, 1996.

Bergamaschi, P., Frankenberg, C., Meirink, J. F., Krol, M., Dentener, F., Wagner, T., Platt, U., Kaplan, J. O., Körner, S., Heimann, M., Dlugokencky, E. J., and Goede, A.: Satellite chartography of atmospheric methane from SCIAMACHY onboard ENVISAT: 2. Evaluation based on inverse model simulations, J. Geophys. Res., 11, D02304, doi:10.1029/2006JD007268, 2007.

Bergamaschi, P., Krol, M., Meirink, J. F., Dentener, F., Segers, A., van Aardenne, J., Monni, S., Vermeulen, A., Schmidt, M., Ramonet, M., Yver, C., Meinhardt, F., Nisbet, E. G., Fischer, R., O'Doherty, S., and Dlugokencky, E. J.: Inverse modeling of European $\mathrm{CH}_{4}$ emissions 2001-2006, J. Geophys. Res., in press, 2010.

Bousquet, P., Ciais, P., Miller, J. B., Dlugokencky, E. J., Hauglustaine, D. A., Prigent, C., Van der Werf, G. R., Peylin, P., Brunke, E.-G., Carouge, C., Langenfelds, R. L., Lathière, J., Pap, F., Ramonet, M., Schmidt, M., Steele, L. P., Tyler, S. C., and White, J.: Contribution of anthropogenic and natural sources to atmospheric methane variability, Nature, 443, 439-443, 2006.

Bustamante, M. M. C., Keller, M., and Silva, D. A.: Sources and Sinks of Trace Gases in Amazonia and the Cerrado, in Amazonia and Global Change edited by: Keller, M., Geophys. Monogr. Ser., 186, AGU, 10.1029/2008GM000847, 2010.

Chen, H., Winderlich, J., Gerbig, C., Hoefer, A., Rella, C. W., Crosson, E. R., Van Pelt, A. D., Steinbach, J., Kolle, O., Beck, V., Daube, B. C., Gottlieb, E. W., Chow, V. Y., Santoni, G. W., and Wofsy, S. C.: High-accuracy continuous airborne measurements of greenhouse gases $\left(\mathrm{CO}_{2}\right.$ and $\left.\mathrm{CH}_{4}\right)$ using the cavity ringdown spectroscopy (CRDS) technique, Atmos. Meas. Tech., 3, 375-386, doi:10.5194/amt-3-375-2010, 2010.

Chen, Y.-H. and Prinn, R. G.: Estimation of atmospheric methane emissions between 1996 and 2001 using a threedimensional global chemical transport model, J. Geophys. Res., 111, D10307, doi:10.1029/2005JD006058, 2006.

Christensen, T., Prentice, I. C., Kaplan, J., Haxeltine, A., and Sitch, S.: Methane flux from northern wetlands and tundra, Tellus, 48B, 652-661, 1996.

Crevoisier, C., Nobileau, D., Fiore, A. M., Armante, R., Chédin, A., and Scott, N. A.: Tropospheric methane in the tropics - first year from IASI hyperspectral infrared observations, Atmos. Chem. Phys., 9, 6337-6350, doi:10.5194/acp-9-6337-2009, 2009.

Crill, P. M., Bartlett, K. B., Wilson, J. O., Sebacher, D. I., Harriss, R. C., Melack, J. M., MacIntyre, S., Lesack, L., and Smith-Morrill, L.: Tropospheric Methane from an Amazonian Foodplain Lake, J. Geophys. Res., 93, 1564-1570, 1988. 
Deutscher, N. M., Griffith, D. W. T., Paton-Walsh, C., and Borah, R.: Train-borne measurements of tropical methane enhancements from ephemeral wetlands in Australia, J. Geophys. Res., 115, D15304, doi:10.1029/2009JD013151, 2010.

Devol, A. H., Richey, J. E., Forsberg, B. R., Martinelli, L. A.: Seasonal Dynamics in Methane Emissions from the Amazon River Floodplain to the Troposphere, J. Geophys. Res., 95, 417-426, 1990.

Drevet, J.: Modeling Study of thr Interannual Variability in Global Tropospheric Hydroxyl Radical and Methane Concentrations Over the Last Two Decades, Dissertation, Ecole Polytechnique Fédérale de Lausanne, 2008.

Edwards, M. O.: Global gridded elevation and bathymetry (ETOPO5), Digital raster data on a 5-minute geographic (lat/lon) $2160 * 4320$ (centroid-registered) grid, NOAA Natl. Geophys. Data Cent., Boulder, CO, USA, 1989.

Frankenberg, C., Meirink, J. F., Bergamaschi, P., Goede, A. P. H., Heimann, M., Körner, S., Platt, U., van der Weele, M., and Wagner, T.: Satellite chartography of atmospheric methane from SCIAMACHY onboard ENVISAT: Analysis of the years 2003 and 2004, J. Geophys. Res., 111, D07303, doi:10.1029/2005JD006235, 2006.

Frankenberg, C., Bergamaschi, P., Butz, A., Houweling, S., Meirink, J. F., Notholt, J., Petersen, A. K., Schrijver, H., Warneke, T., and Aben, I.: Tropical methane emissions: A revised view from SCIAMACHY onboard ENVISAT, Geophys. Res. Lett., 35, L15811, doi:10.1029/2008GL034300, 2008.

Frankenberg, C., Aben, I., Bergamaschi, P., Dlugokenchy, E. J., van Hees, R., Houweling, S., van der Meer, P., Snel, R., and Tol, P.: Global column-averaged methane mixing ratios from 2003 to 2009 as derived from SCIAMACHY: Trends and variability, J. Geophys. Res., 116, D04302, doi:10.1029/2010JD014849, 2011.

Freitas, S. R., Longo, K. M., and Andreae, M. O.: Impact of including the plume rise of vegetation fires in numerical simulations of associated atmospheric pollutants, Geophys. Res. Lett., 33, L17808, doi:10.1029/2006GL026608, 2006.

Freitas, S. R., Longo, K. M., Silva Dias, M. A. F., Chatfield, R., Silva Dias, P., Artaxo, P., Andreae, M. O., Grell, G., Rodrigues, L. F., Fazenda, A., and Panetta, J.: The Coupled Aerosol and Tracer Transport model to the Brazilian developments on the Regional Atmospheric Modeling System (CATT-BRAMS) - Part 1: Model description and evaluation, Atmos. Chem. Phys., 9, 2843 2861, doi:10.5194/acp-9-2843-2009, 2009.

Freitas, S. R., Longo, K. M., Alonso, M. F., Pirre, M., Marecal, V., Grell, G., Stockler, R., Mello, R. F., and Sánchez Gácita, M.: PREP-CHEM-SRC - 1.0: a preprocessor of trace gas and aerosol emission fields for regional and global atmospheric chemistry models, Geosci. Model Dev., 4, 419-433, doi:10.5194/gmd-4419-2011, 2011.

Gevaerd, R. and Freitas, S. R.: Estimativa operacional da umidade do solo para iniciação de modelos de previsão numérica da atmosfera. Parte I: Descrição da metodologia e validação, Rev. Brasil. Meteorol., 21, 1-15, 2006.

Grell, G., Peckham, S. E., Schmitz, R., McKeen, S. A., Frost, G., Skamarock, W. C., and Eder, B.: Fully coupled "online" chemistry within the WRF model, Atmos. Environ., 39, 6957-6975, doi:10.1016/j.atmosenv.2005.6904.6027, 2005.

Grell, G., Freitas, S. R., Stuefer, M., and Fast, J.: Inclusion of biomass burning in WRF-Chem: impact of wildfires on weather forecasts, Atmos. Chem. Phys., 11, 5289-5303, doi:10.5194/acp11-5289-2011, 2011.

Hess, L. L., Melack, J. M., Novo, E. M. L. M., Barbosa, C. C. F., and Gastil, M.: Dual-season mapping of wetland inundation and vegetation for the central Amazon basin, Remote Sens. Environ. 87, 404-428, 2003.

Hess, L. L., Affonso, A. A., Barbosa, C., Gastil-Buhl, M., Melack, J. M., and Novo, E. M. L. M.: LBA-ECO LC-07 Basinwide Amazon Wetlands $100 \mathrm{~m}$ Mask based on JERS SAR Images (v.Apr08), data set, available online at: http://lba.cptec.inpe.br/ from LBA Data and Information System (last access: May 2012), National Institute for Space Research (INPE/CPTEC), Cachoeira Paulista, Sao Paulo, Brazil, 2009.

Intergovernmental Panel on Climate Change - Climate Change 2007: The Physical Science Basis - Fourth Assessment Report of the Intergovernmental Panel on Climate Change, Cambridge Univ. Press, New York, USA, 2007.

Kaplan, J. O.: Wetlands at the Last Glacial Maximum: Distribution and methane emissions, Geophys. Res. Lett., 29, 1079 , doi:10.1029/2001GL013366, 2002.

Kaplan, J. O., Folberth, G., and Hauglustaine, D. A.: Role of methane and biogenic volatile organic compound sources in late glacial and Holocene fluctuations of atmospheric methane concentrations, Global Biogeochem. Cy., 20, GB2016, doi:10.1029/2005GB002590, 2006.

Kort, E. A., Eluszkiewicz, J., Stephens, B. B., Miller, J. B., Gerbig, C., Nehrkorn, T., Daube, B. C., Kaplan, J. O., Houweling, S., and Wofsy, S. C.: Emissions of $\mathrm{CH}_{4}$ and $\mathrm{N}_{2} \mathrm{O}$ over the United States and Canada based on a receptor-oriented modeling framework and COBRA-NA atmospheric observations, Geophys. Res. Lett., 35, L18808, doi:10.1029/2008GL034031, 2008.

Knorr, W.: Satellite remote sensing and modelling of the global $\mathrm{CO}_{2}$ exchange of land vegetation: A sythesis study, dissertation, MaxPlanck-Inst. für Meteorol., Hamburg, Germany, 1997.

Lin, J., Gerbig, C., Wofsy, S. C., Andrews, A. E., Daube, B. C., Davis, K. J., and Grainger, C. A.: A near-field tool for simulating the upstream influence of atmospheric observations: The Stochastic Time-Inverted Lagragian Transport (STILT) model, J. Geophys. Res., 108, 4493, doi:10.1029/2002JD003161, 2003.

Longo, K. M., Freitas, S. R., Andreae, M. O., Setzer, A., Prins, E., and Artaxo, P.: The Coupled Aerosol and Tracer Transport model to the Brazilian developments on the Regional Atmospheric Modeling System (CATT-BRAMS) - Part 2: Model sensitivity to the biomass burning inventories, Atmos. Chem. Phys., 10, 5785-5795, doi:10.5194/acp-10-5785-2010, 2010.

Mahadevan, P., Wofsy, S. C., Matross, D. M., Xiao, X., Dunn, A. L., Lin, J. C., Gerbig, C., Munger, J. W., Chow, V. Y., and Gottlieb, E. W.: A satellite-based biosphere parameterization for net ecosystem $\mathrm{CO}_{2}$ exchange: Vegetation Photosynthesis and Respiration Model (VPRM), Global Biogeochem. Cy., 22, GB2005, doi:10.1029/2006GB002735, 2008.

Melack, J. M., Hess, L. L., Gastil, M., Forsberg, B. R., Hamilton, S. K., Lima, I. B. T., and Novo, E.: Regionalization of methane emissions in the Amazon basin with microwave remote sensing, Global Change Biol., 10, 530-544, 2004.

Miller, J. B., Gatti, L. V., d'Amelio, M. T. S., Crotwell, A. M., Dlugokencky, E. J., Bakwin, P., Artaxo, P., and Tans, P. P.: Airborne measurements indicate large methane emissions from the eastern Amazon basin, Geophys. Res. Lett., 34, L10809, 
doi:10.1029/2006GL029213, 2007.

Olivier, J. G. J., Bouwman, A. F., Van der Maas, C. W. M., Berdowski, J. J. M., Veldt, C., Bloos, J. P. J., Visschedijk, A. J. H., Zandveld, P. Y. J., and Haverlag, J. L.: Description of EDGAR Version 2.0: a set of global emission inventories of greenhouse gases and ozone depleting substances for all anthropogenic and most natural sources on a per country basis and on 18_18 grid. RIVMTechnical Report No. 771060 002; TNO-MEP Report No. R96/119. National Institute of Public Health and the Environment, Bilthoven/Netherlands Organisation for Applied Scientific Research, Apeldoorn, 1996.

Olivier, J. G. J., Bouwman, A. F., Berdowski, J. J. M., Veldt, C., Bloss, J. P. J., Visschedijj, A. H. J., van de Maas, C. W. M., and Zandweld, P. Y. J.: Sectoral emission inventories of greenhouse gases for 1990 on per country basis as well as $10 \times 10$, Environ. Sci. Policy, 2, 241-264, 1999.

Petersen, A. K., Warneke, T., Frankenberg, C., Bergamaschi, P., Gerbig, C., Notholt, J., Buchwitz, M., Schneising, O., and Schrems, O.: First ground-based FTIR observations of methane in the inner tropics over several years, Atmos. Chem. Phys., 10, 7231-7239, doi:10.5194/acp-10-7231-2010, 2010.

Pickett-Heaps, C. A., Jacob, D. J., Wecht, K. J., Kort, E. A., Wofsy, S. C., Diskin, G. S., Worthy, D. E. J., Kaplan, J. O., Bey, I., and Drevet, J.: Magnitude and seasonality of wetland methane emissions from the Hudson Bay Lowlands (Canada), Atmos. Chem. Phys., 11, 3773-3779, doi:10.5194/acp-11-3773-2011, 2011.

Pillai, D., Gerbig, C., Marshall, J., Ahmadov, R., Kretschmer, R., Koch, T., and Karstens, U.: High resolution modeling of $\mathrm{CO}_{2}$ over Europe: implications for representation errors of satellite retrievals, Atmos. Chem. Phys., 10, 83-94, doi:10.5194/acp-1083-2010, 2010.

Pillai, D., Gerbig, C., Ahmadov, R., Rödenbeck, C., Kretschmer, R., Koch, T., Thompson, R., Neininger, B., and Lavrié, J. V.: High-resolution simulations of atmospheric $\mathrm{CO} 2$ over complex terrain - representing the Ochsenkopf mountain tall tower, Atmos. Chem. Phys., 11, 7445-7464, doi:10.5194/acp-11-74452011, 2011.

Prigent, C., Matthews, E., Aires, F., and Rossow, W. B.: Remote sensing of global wetland dynamics with multiple satellite data sets, Geophys. Res. Lett., 28, 4631-4634, 2001.

Prigent, C., Papa, F., Aires, F., Rossow, W. B., and Matthews, E.: Global inundation dynamics inferred from multiple satellite observations, 1993-2000, J. Geophys. Res., 112, D12107, doi:10.1029/2006JD007847, 2007.

Prigent, C., Papa, F., Aires, F., Jiminez, C., Rossow, W. B., and Matthews, E.: Changes in land surface water dynamics since the 1990s and relation to population pressure, Geophys. Res. Lett., 39, L08403, doi:10.1029/2012GL051276, 2012.
Prins, E. M., Feltz, J. M., Menzel, W. P., and Ward, D. E.: An overview of GOES-8 diurnal fire and smoke results for SCAR-B and 1995 fire season in South America, J. Geophys. Res., 103, 31821-31835, 1998.

Ridgwell, A. J., Marshall, S. J., and Gregson, K.: Consumption of atmospheric methane by soils: A process-based model, Global Biochem. Cy., 13, 59-70, 1999.

Sanderson, M. G.: Biomass of termites and their emissions of methane and carbon dioxode: A global database, Global Biochem. Cy., 10, 543-557, 1996.

Schlesinger, W. H.: Biogeochemistry: an analysis of global change, Academic Press, San Diego, CA, USA, 1997.

Sestini, M., Reimer, E., Valeriano, D., Alvalá, R., Mello, E., Chan, C., and Nobre, C.: Mapa de cobertura da terra da Amazônia legal para uso em modelos meteorológicos, Anais XI Simpósio Brasileiro de Sensoriamento Remoto, 2901-2906, 2003.

Sitch, S., Smith, B., Prentice, I. C., Arneth, A., Bondeau, A., Cramer, W., Kaplan, J. O., Levis, S., Lucht, W., Sykes, M. T., Thonicke, K., and Venevsky, S.: Evaluation of ecosystem dynamics, plant geography and terrestrial carbon cycling in the LPJ dynamic global vegetation model, Global Change Biol., 9, 161185, 2003.

Taylor, K. E.: Summarizing multiple aspects of model performance in a single diagram, J. Geophys. Res., 116, 7183-7192, 2001.

Vermeulen, A. T., Eismaa, R., Hensen, A., and Slanina, J.: Transport model calculations of NW-European methane emissions, Environ. Sci. Policy, 2, 315-324, 1999.

Walter, B. P., Heimann, M., Shannon, R. D., and White, J. R.: A process-based model to derive methane emissions from natural wetlands, Geophys. Res. Lett., 23, 3731-3734, 1996.

Walter, B. P. and Heimann, M.: A process-based, climate-sensitive model to derive methane emissions from natural wetlands: Application to five wetland sites, sensitivity to model parameters, and climate, Global Biochem. Cy., 14, 745-765, 2000.

Walter, B. P., Heimann, M., and Matthews, E.: Modeling modern methane emissions from natural wetlands 1 . Model description and results, J. Geophys. Res., 106, 34189-34206, 2001 a.

Walter, B. P., Heimann, M., and Matthews, E.: Modeling modern methane emissions from natural wetlands 2 . Interannual variations 1982-1993, J. Geophys. Res., 106, 34207-34219, 2001 b.

Wuebbles, D. J. and Hayhoe, K.: Atmospheric methane and global change, Earth-Science Reviews, 57, 177-210, 2002.

Zhao, C., Andrews, A. E., Bianco, L., Eluszkiewicz, J., Hirsch, A., MacDonald, C., Nehrkorn, T., and Fischer, M. L.: Atmospheric inverse estimates of methane emissions from Central California, J. Geophys. Res., 114, D16302, doi:10.1029/2008JD011671, 2009. 